\title{
Systemic perspectives on scaling agricultural innovations. A review
}

\author{
Seerp Wigboldus ${ }^{1,2}$ - Laurens Klerkx ${ }^{2}$ - Cees Leeuwis ${ }^{2}$ - Marc Schut ${ }^{2,3}$. \\ Sander Muilerman ${ }^{2,4} \cdot$ Henk Jochemsen ${ }^{5}$
}

Accepted: 4 July 2016/Published online: 9 August 2016

(C) The Author(s) 2016. This article is published with open access at Springerlink.com

\begin{abstract}
Agricultural production involves the scaling of agricultural innovations such as disease-resistant and droughttolerant maize varieties, zero-tillage techniques, permaculture cultivation practices based on perennial crops and automated milking systems. Scaling agricultural innovations should take into account complex interactions between biophysical, social, economic and institutional factors. Actual methods of scaling are rather empirical and based on the premise of 'find out what works in one place and do more of the same, in another place'. These methods thus do not sufficiently take into account complex realities beyond the concepts of innovation transfer, dissemination, diffusion and adoption. As a consequence, scaling initiatives often do not produce the desired effect. They may produce undesirable effects in the form of negative spill-overs or unanticipated side effects such as environmental degradation, bad labour conditions of farm workers and loss of control of farming communities over access to genetic resources. Therefore, here, we conceptualise scaling processes as an integral part of a systemic approach to
\end{abstract}

Seerp Wigboldus

seerp.wigboldus@wur.nl

1 Centre for Development Innovation, Wageningen UR (University and Research Centre), P.O. Box 88, 6700

AB Wageningen, The Netherlands

2 Knowledge, Technology and Innovation Group, Wageningen University, P.O. Box 8130, 6700 EW Wageningen, The Netherlands

3 International Institute of Tropical Agriculture (IITA), Quartier Kabondo, Rohero 1, Avenue 18 Septembre 10, Bujumbura, Burundi

4 International Institute of Tropical Agriculture (IITA), Airport Residential Area, CSIR Campus, P.O. Box M32, Accra, Ghana

5 Philosophy Group, Wageningen University, P.O. Box 8130, 6700 EW Wageningen, The Netherlands innovation, to anticipate on the possible consequences of scaling efforts. We propose a method that connects the heuristic framework of the multi-level perspective on socio-technical transitions (MLP) to a philosophical 'modal aspects' framework, with the objective of elucidating the connectedness between technologies, processes and practices. The resultant framework, the PRactice-Oriented Multi-level perspective on Innovation and Scaling (PROMIS), can inform research and policymakers on the complex dynamics involved in scaling. This is illustrated in relation to three cases in which the framework was applied: scaling agro-ecological practices in Nicaragua, farmer field schools on cocoa cultivation in Cameroon and 'green rubber' cultivation in Southwest China.

Keywords Systemic analysis · Innovation systems · Diffusion of innovations · Adoption of innovations · Technology transfer $\cdot$ Responsible innovation - Sustainability transitions $\cdot$ Upscaling $\cdot$ Outscaling

\section{Contents}

1 Introduction

2 Towards a framework for systemic analysis of scaling processes

2.1 Building on the multi-level perspective on sociotechnical transitions

2.2 Complementing the multi-level perspective with the theory of aspects

2.3 PROMIS as an integrative analytical framework

3 Enriching perspectives on scaling processes by applying the PROMIS framework

3.1 Analysing regime configurations in which scaling takes place

3.2 Strategic analysis of anticipated scaling dynamics 
3.3 Understanding different stakeholders' roles in scaling

3.4 Supporting stakeholders in future-oriented analysis of scaling

4 Using the PROMIS framework in research: early experiences

5 Conclusion: current contribution of PROMIS and next steps

Acknowledgments

References

\section{Introduction}

Increasingly, development agencies, governments and donors assess the impact of agricultural research and innovation by the extent to which outputs and outcomes in the form of novel technologies and practices can lead to wider benefits (Joly et al. 2015). This is often referred to as a process of 'scaling' to achieve 'impact at scale' (e.g. Anderson 2012; Clark et al. 2012; Little 2012; Millar and Connell 2010). Scaling processes are conceptualised in various ways, with a distinction often being made between scaling up and scaling out (e.g. Anderson 2012; Menter et al. 2004; Millar and Connell 2010). Scaling up means something similar to increasing (e.g. in terms of numbers, speed, size), whereas scaling out often relates to expanding, such as geographically spreading the use of a particular technology. In this paper, we use the overall term, scaling. A prominent assumption underpinning most scaling initiatives is that, if products, processes or practices go to scale, (positive) impact will scale with it, hence the common approach of 'find out what works (in one place) and do more of the same (elsewhere)' (Fig. 1). In this approach, transfer and dissemination leading to diffusion and adoption are frequently used concepts (German et al. 2006; Kuehne et al. 2013; Maredia 2014; Reimer et al. 2012; Schewe and Stuart 2015). There are two important problems with this approach in relation to understanding the complexity of scaling.

Firstly, it is increasingly recognised that transfer and dissemination, and related to that diffusion and adoption, of technologies and practices are not linear processes; rather, substantial reworking of technologies and practices happens in scaling processes (Douthwaite et al. 2001; Millar and Connell 2010;

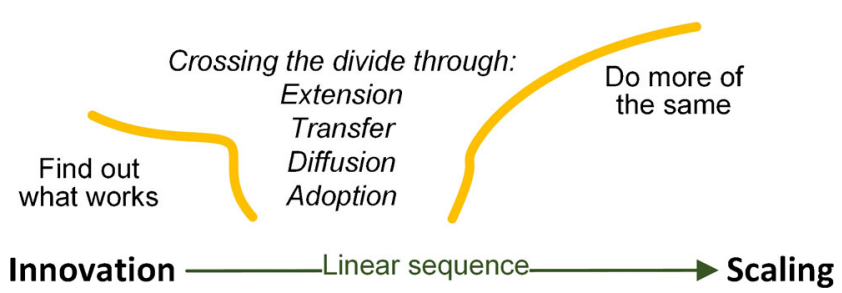

Fig. 1 Scaling (up) as a linear process
Garb and Friedlander 2014). However, approaches to scaling using concepts such as adoption, transfer and dissemination (e.g. Abebawa and Haile 2013; Dibba et al. 2012; Peshin 2013; Rogers 1983; Wejnert 2002) tend to focus mainly on attributes of technologies and adopters that determine adoption likelihood. They do not always prepare prospective users sufficiently to engage with the systemic and complex dynamics involved in, and resulting from, scaling processes. Adoption thinking does consider the importance of social networks as an influencing factor in farmers' behaviour in relation to, for example, the adoption of more sustainable practices (Pannell et al. 2006) and increasingly looks at how configurations of social networks influence adoption behaviour (Aguilar-Gallegos et al. 2015; Hoang et al. 2006; Spielman et al. 2011; Thuo et al. 2014). However, adoption thinking tends to remain focused on informing interventions (e.g. policies) aimed at farm level and is less explicit about interventions that create a conducive environment for change overall (e.g. by changing value chains and markets, consumption patterns, citizen values). Furthermore, adoption approaches and studies tend to focus on transfer and dissemination success, such as the number of farmers using a particular technology, and much less on long-term, cross-domain and cross-scale consequences of dissemination and diffusion.

Secondly, work on scaling, using concepts such as transfer and dissemination, and diffusion and adoption, focuses on what works in a particular ecological, geographical or sociocultural area, but technologies and practices do not necessarily work, and may even have negative effects, in other areas (Coe et al. 2014; Garb and Friedlander 2014; Gee et al. 2013; Menter et al. 2004). Technologies and practices that are perceived as sustainable and inclusive may even work out quite differently when applied at large scale or under different ecological, geographical or political conditions (e.g. Menter et al. 2004; Rotmans and Rothman 2003; Schulze 2000; Wu et al. 2006). For example, rubber cultivation was seen as a way out of poverty in Southwest China, but, when it eventually covered one-third of the landscape, environmental degradation became dramatic (Xu et al. 2014; Ziegler et al. 2009) (Fig. 2). Hence, what is promoted as a solution and scaled at one point in time may later be considered an environmental hazard (EASAC 2015; Gee et al. 2013). When something has gone to scale, it may be difficult to scale it down again, even if it produces negative side effects (Scheffer et al. 2009; Scheffer 2010; Ziegler et al. 2009; van den Berg et al. 2012). Many of these concerns inspired the development of ideas regarding 'responsible innovation' (McNaghten et al. 2014; Stilgoe et al. 2013; Stirling 2015; van den Hoven et al. 2014), in which possible negative effects are anticipated; this eventuality applies also to scaling (hence this is seen as 'responsible innovation and scaling' - see Table 1). These ideas are becoming increasingly important given the debates on 'contested agronomy' that emphasise the politics of 


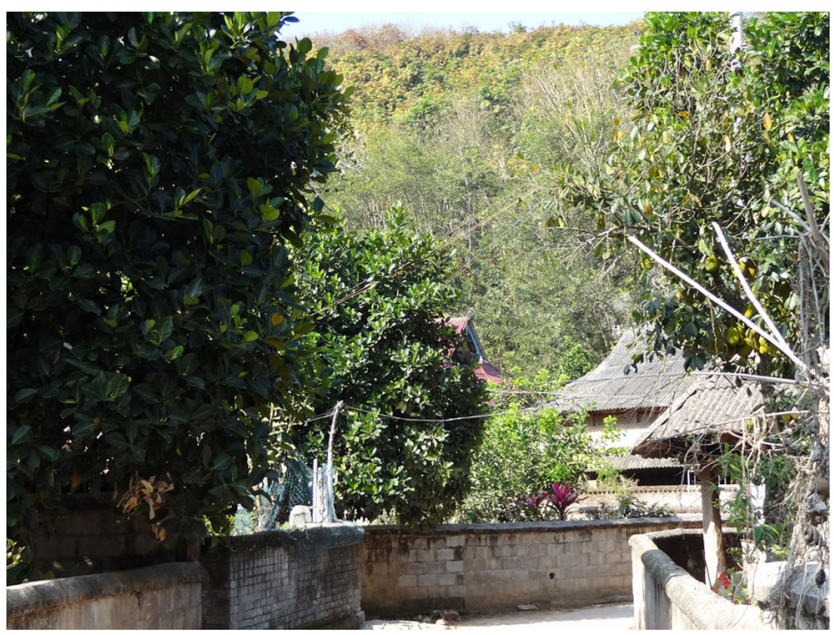

Fig. 2 Scaling rubber cultivation in SW-China brought financial affluence to many communities, but also eroded biophysical and cultural diversity at scale

technology development and scaling (Sumberg et al. 2013). Some authors have suggested that our capacity for technological innovation is increasingly exceeding our capacity to foresee the long-term impact of technologies and practices (Gee et al. 2013; Koohafkan et al. 2012). We would argue that scaling dynamics are at the heart of such concerns, as they create a multiplier effect on potential negative outcomes. This effect may, for example, relate to increased vulnerability due to dependency on monocultures, as happened as early as the nineteenth century in the case of potatoes in Ireland (Woodham-Smith 1962). It may also relate to depletion or contamination of resources, which happened, for example, in Bangladesh due to scaling of ground water extraction (Hossain 2006).

The above reflections illustrate how many scaling processes involve complex dynamics that should be addressed not only in the dissemination or adoption stage, but also in the design and development of technologies and practices to inform 'best bets' and 'best fits'. Concerns about this issue have led some to advocate for participatory design and best-fit

Table 1 Dimensions of responsible scaling (adapted from Stilgoe et al. 2013)

Anticipatory: Anticipating 'what if this goes to scale?' as well as anticipating what emerging futures the scaling process may need to connect to (e.g. in terms of trends)

Responsive: Responding to both societal needs and societal concerns expressed by all stakeholders; this involves considering all aspects as discussed in this paper

Reflexive: Reflexive and adaptive management informed by ongoing evaluation of the functionality of scaling up in view of a defined purpose, rather than mere rolling out of blue-print 'solutions'

Inclusive: Inclusive in scope (what is in the picture): inclusive in process (collaborative): inclusive in effort (convergence), and inclusive in terms of who benefits options, requiring processes of adaptation and translation (Cerf et al. 2012; Garb and Friedlander 2014; Giller et al. 2011; Klerkx et al. 2010; Knowler and Bradshaw 2007; Shiferaw et al. 2009; van der Stoep and Strijbos 2011). This implies that, rather than being considered as the logical follow up of novel technologies and practices that resulted from successful research and innovation, scaling should be considered as part of a more continuous process involving ongoing finetuning (Fig. 3). In this perspective, research and innovation need to anticipate such adaptive (scaling) processes and therefore design with future (potential) scaling up in mind (Expandnet 2011; Ghiron et al. 2014; Middleton et al. 2005). This involves making scaling processes a more integral part of systemic approaches to innovation (Blesh and Wolf 2014; Foran et al. 2014; Hinrichs 2014; Klerkx et al. 2010).

To be able to address scaling processes from a richer and systemic perspective, we need integrative approaches to design and guide scaling initiatives as well as analytical frameworks to support this. Based on a review of literature on scaling and system innovation, this paper proposes a systemic framework to address the multiple dimensions and dynamics which should be taken into consideration during scaling processes. To this end, the paper addresses three main questions: - What existing systemic perspectives, approaches and frameworks provide a good basis for developing an analytical framework for understanding the dimensions and dynamics involved in scaling processes (Section 2)?

- How can the identified approaches translate into an integrative analytical framework that activates a systemic perspective on innovation and scaling (Section 2)?

- How could such a framework be used to assess and inform scaling initiatives (Sections 3 and 4)?

By addressing these questions, we seek to contribute to improved analysis, decision making and policymaking in relation to scaling initiatives by providing richer perspectives than those commonly informing scaling initiatives today. Insights are meant to be first of all be of use to researchers, policymakers, and certainly to those responsible for designing and managing projects which include a clear scaling ambition. This initial approach provides an example of how perspectives on scaling processes may be

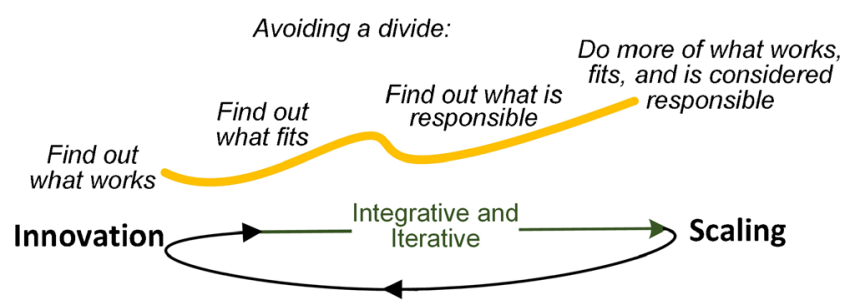

Fig. 3 Scaling (up) as an integrative and iterative process 
enriched while requiring further research and refinement on the basis of empirical studies.

In Section 4, we briefly explore ways in which the analytical approach as outlined in Sections 2 and 3 can be used. In the conclusions (Section 5), we briefly reflect on the approach, what it contributes, its limitations and on options for further research and development.

\section{Towards a framework for systemic analysis of scaling processes}

\subsection{Building on the multi-level perspective on socio-technical transitions}

In search of approaches that already include specific analytical frameworks in relation to scaling processes, we selectively reviewed the literature to explore a range of integrated approaches in view of our purpose to build and integrative framework. Thus, review was not exhaustive, which could be seen as a limitation, but as the aim of our paper is to build an integrative systemic framework to analyse scaling, we had to balance width and depth of the review. The purpose of the review was hence not to analyse and compare all approaches in detail but to enable making an informed selection of the approaches useful for our framework. The approaches reviewed include agricultural systems approaches (e.g. Darnhofer et al. 2010; Garb and Friedlander 2014; van Ittersum et al. 2008; Klerkx et al. 2012; Miller and Newell 2013; Schut et al. 2014a, b), interdisciplinary (e.g. Frodeman et al. 2010; Wagner et al. 2011) and transdisciplinary (e.g. Brandt 2013; Klein 2014; Pohl and Hirsch Hadorn 2007) research approaches, innovation systems approaches (e.g. Lamprinopoulou et al. 2014; Schut et al. 2014a, b, 2015a, b; Spielman et al. 2009), value chain approaches (e.g. Ashby et al. 2012; Nang'ole et al. 2011), landscape approaches (e.g. Freeman et al. 2015; Kozar et al. 2014; Sayer et al. 2014; Wu 2013) and socio-ecological systems approaches (Foran et al. 2014; Sinclair et al. 2014; Westley et al. 2013). Although issues of scale do feature in them, such approaches offer no analytical frameworks for developing systemic and integrative perspectives on scaling processes. The call for 'integrative' approaches to research and innovation (e.g. Fischer et al. 2012; van Kerkhoff 2014; Veldkamp et al. 2009; Weichselgartner and Kasperson 2010) thus rarely includes a plea for integrative and systemic approaches that also pertain to scaling processes. This may be one reason why our understanding about scaling processes tends to remain fragmented regarding what is involved in the success or failure of scaling initiatives (Volk and Ewert 2011; Willemen et al. 2013).

Approaches relating to the study of transitions to sustainability (Elzen et al. 2012; Geels 2002; Hinrichs 2014; Horlings and Marsden 2011; Kemp et al. 1998; Kemp and
Rotmans 2009; Rotmans 2003), however, already include perspectives on scaling. They help develop more of a 'biggerpicture' perspective, required for a more comprehensive approach. They are, however, less explicit regarding the specific dimensions and dynamics involved in transitions and associated scaling processes. We therefore chose to build, but also to elaborate further, on the related multi-level perspective (MLP) on socio-technical transitions (Geels 2002). We first briefly introduce MLP and then discuss our suggestions about addressing some of its limitations.

MLP was designed to better illustrate and interpret how radical innovations connect to socio-technical transition processes (Geels 2002). It is a perspective that is increasingly applied in the context of agriculture (e.g. Blesh and Wolf 2014; Diaz et al. 2013; Elzen et al. 2011, 2012; Hinrichs 2014; Ingram 2015; Lamine 2011; Morrissey et al. 2014; Sutherland et al. 2015). If this perspective is applied to scaling, it provides insight regarding the dynamics that influence why some innovations go to scale and others do not. The multilevel perspective incorporates three main levels: niche, regime and landscape (Fig. 4). Although some authors (e.g. Diaz et al. 2013; Geels 2014; Papachristos et al. 2013) have recently suggested adaptations of the original model, it still revolves around these levels, and the studies mentioned above in relation to agriculture use it in this way.

The regime level relates to the constellation or system of interacting practices and structures that have come to a certain relative stability and status quo. This may, for example, be the status quo in a sector. This stability may, however, be disturbed (perturbed), e.g. as a result of new policies or of changing environmental conditions. This may create opportunities for novelties (innovations) to become incorporated in, and change, a regime, particularly those that address or even create such disturbance (perturbation). Novelties (innovations) can benefit from sheltered conditions that favour their emergence (and scaling), for example through dedicated project funding. This is called the niche (level) in which novelties develop. Figure 4 suggests that niches come from outside the regime, but sometimes novelties - and, related to that, niches - also develop within regimes (Geels 2011). The landscape within which this happens may be understood as the wider context, and it is considered to be the least dynamic level relating to, e.g. worldviews, paradigms, culture and politics, which tend to change slowly.

At regime level, MLP describes incumbent systems that involve dominant configurations relating to, e.g. science, infrastructure, markets and technology, and that have established 'institutional logics' (Fünfschilling and Truffer 2014). These logics are defined as 'the socially constructed, historical patterns of material practices, assumptions, values, beliefs, and rules by which individuals produce and reproduce their material subsistence, organize time and space, and provide meaning to their social reality' (Thornton and Ocasio 
Fig. 4 The multi-level perspective, based on Geels $(2002,2011)$

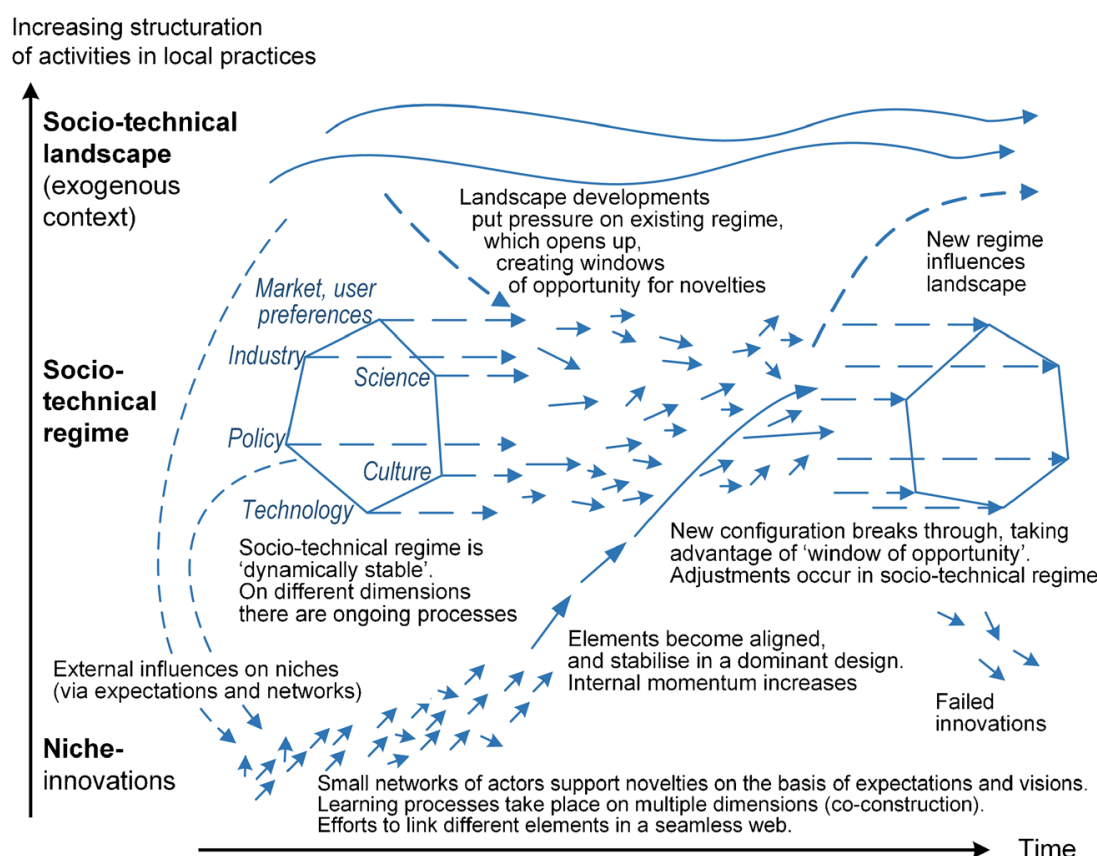

1999, p. 804). It also points to a range of dynamics involved in related transitions (hence the many arrows in Fig. 4). Regimes are usually not deliberately shaped, but rather the outcome of path dependencies leading to a state of being locked into a status quo (e.g. a dominant way of agricultural production) as a result of interdependencies which developed between actors and processes (Holtz et al. 2008; Fünfschilling and Truffer 2014). Such lock-in often involves power relations where some groups (e.g. proponents of a particular model of agricultural production) may have a vested interest in maintaining such status quo while it conflicts with the interests and aspirations of other groups (Avelino and Rotmans 2009; Olsson et al. 2014; Avelino and Wittmayer 2015). Path dependence includes notions regarding causal relationships in which seemingly small events can set in motion much wider historical paths through often non-linear and difficult-to-trace processes (Castro et al. 2014; Ruttan 1996). The economic concept of path dependence explains how the set of decisions faced for any given circumstance is limited by decisions made in the past, even though the past circumstances may no longer exist (Liebowitz and Margolis 1995).

Scaling novel agricultural technologies and practices often involves changes in multiple regime elements (e.g. in production systems, but also markets and consumption systems) and may relate to multiple regimes. For example, care farming intersects the farming regime and the care regime (Hassink et al. 2013), and the farming regime overlaps with the energy regime in the case of biofuels (Sutherland et al. 2015). Novel technologies and practices may sometimes drastically change a regime (radical innovations, e.g. a shift from tillage to zero tillage, a shift from intuitive farmer decision making to bigdata-driven decision making in precision farming), but sometimes they may affect only parts of the regime when innovation are (in parts) incremental, e.g. using biofuel in tractors (Geels and Schot 2007). Some criticisms have been voiced about the MLP, the first one being that it is too 'coarse' a framework, in which insufficient attention is paid to unravelling the role of everyday practices and people's agency in niches and regimes (Geels 2011; Genus and Coles 2008; Shove and Walker 2007, 2010). Furthermore, given the focus on socio-technical transitions, biophysical and socioecological elements are less highlighted in the regime concept, as well as notions of geographical scales (Coenen et al. 2012; Hansen and Coenen 2015) whereas they are highly important in the context of agriculture (Dalgaard et al. 2003; Diaz et al. 2013; Foran et al. 2014; Sinclair et al. 2014). Lastly, notions of responsible innovation have so far been less explicitly considered in MLP, although they are mentioned as important and a promising avenue for the further development of MLP (Pesch 2014).

\subsection{Complementing the multi-level perspective with the theory of aspects}

To overcome some of MLP's limitations, we suggest to complement, or rather refine it, to better define the different regime and landscape elements (see also Fünfschilling and Truffer 2014; Holtz et al. 2008), how they are perceived by people, and how analysis and decisions regarding sustainability and responsible scaling can be informed. The theory of modal aspects, developed by the Dutch philosopher Herman Dooyeweerd, provides a suite of aspects of experienced reality (Basden 2008; Brandon and Lombardi 2011; Jahanyan and Fard 2012; Ribeiro et al. 2012; Strijbos and Basden 2006) 
and has previously been used as a framework for evaluating sustainable development (Brandon and Lombardi 2011; Jochemsen 2012; Massink 2013). The theory of aspects helps to elucidate the connectedness of (change) dimensions and dynamics, and enhances the capacity to create integrated (including cross-system) perspectives to grasp the complexities involved in scaling.

Table 2 presents a framework based on the theory of aspects, indicating the particular sequence of aspects with examples of what these aspects pertain to. We have slightly adapted the original suite of 15 aspects and have related it to the notion of 'capitals' as used in agricultural development and resilience studies (e.g. Bebbington 1999; Berkes and Folke 1992; Knutsson 2006; Scoones 1998; Stokols et al. 2013).

The aspects in the framework (Table 2) refer to ways in which we experience reality. They are also referred to as distinct perspectives on experienced reality, i.e. on all things (entities, including social structures and events), on the basis of which things and events can be evaluated. They help explain the diversity and coherence of everyday experience, and together they provide an integrative perspective on things and events. They are ordered in a particular way, with each aspect, apart from the quantitative, adding a dimension to the preceding one. For example, the biotic requires the quantitative, the spatial, the kinematic and the physical. Each aspect has a particular core value and each has its own distinct place in the totality of aspects. No aspect can be reduced to another one, but they are all intrinsically linked (Basden 2015). An underlying assumption of the theory of aspects is that simultaneously paying due attention to the various aspects supports sustainability. Scientific disciplines usually focus on one or two specific aspects, but complex problems such as those generally related to scaling usually involve many (Schut et al. 2014a, b). The theory of aspects offers a basis for systematically characterising and then comparing technologies, processes, practices and systems along the lines of the aspects. Because this framework based on the theory of aspects allows for such broad-based application, innovation and scaling processes can be analysed across levels, scales, domains and

Table 2 Aspects in relation to which entities can be characterised

\begin{tabular}{|c|c|c|}
\hline Aspects of experienced reality & What it pertains to & $\begin{array}{l}\text { Examples of entities that distinguish themselves from other } \\
\text { entities primarily along the lines of that aspect }\end{array}$ \\
\hline \multicolumn{3}{|l|}{ Natural and physical capital } \\
\hline $\begin{array}{l}\text { Quantitative, spatial, kinematic, } \\
\text { physical }\end{array}$ & $\begin{array}{l}\text { Discrete quantity, continuous (spatial) } \\
\text { extension, motion, energy, and matter }\end{array}$ & $\begin{array}{l}\text { Numbers, location, atmosphere, climate, water, soil, natural } \\
\text { forces, chemistry, transportation, infrastructure, buildings, } \\
\text { equipment }\end{array}$ \\
\hline Biotic, sensitive & Non-human life and vitality, feeling & $\begin{array}{l}\text { Plants, animals, birds, fish, organic processes, ecosystem, } \\
\text { biodiversity, forest, desert, habitat, farm, crops, livestock, } \\
\text { animal behaviour }\end{array}$ \\
\hline \multicolumn{3}{|l|}{ Human capital } \\
\hline Biotic, sensitive & Human life and vitality, feeling & $\begin{array}{l}\text { Awareness, health, physical and mental abilities, emotion, } \\
\text { personality, disposition, passion, observation, population } \\
\text { dynamics, safety }\end{array}$ \\
\hline Analytical-logical & Distinction & $\begin{array}{l}\text { Knowledge, theory, logic, conceptual framework, science, } \\
\text { research, education }\end{array}$ \\
\hline Formative & Formative power & $\begin{array}{l}\text { Construction, creativity, skill, computer software, design, } \\
\text { power (in relationship): technology, strategy, } \\
\text { methodology, innovation, adaptation }\end{array}$ \\
\hline \multicolumn{3}{|l|}{ Social and financial capital } \\
\hline Lingual, social & Symbolic representation, social interaction & $\begin{array}{l}\text { Symbols, signs, language, communication, information, media } \\
\text { Relationships, roles, social cohesion, competition, collaboration, } \\
\text { organisation, societies, alliances, partnerships }\end{array}$ \\
\hline Economic & Frugality & $\begin{array}{l}\text { Resource management, conservation, stewardship, exchange } \\
\text { of goods and services, transactions, efficiency, sustainability, } \\
\text { economy, land use, market, value chain, firm, employment }\end{array}$ \\
\hline \multicolumn{3}{|l|}{ Cultural, political and moral capital } \\
\hline Juridical & What is due & $\begin{array}{l}\text { Rights, law, responsibility, appropriateness, policy, legal system, } \\
\text { constitution, mandate, police, the state, democracy, ownership }\end{array}$ \\
\hline Aesthetical, ethical, certitudinal & $\begin{array}{l}\text { Harmony } \\
\text { love (self-giving) } \\
\text { faith and vision }\end{array}$ & $\begin{array}{l}\text { Appeal, beauty, enjoyment, leisure, sports, art } \\
\text { Attitude, care, sharing, goodwill, integrity, equity, being right, } \\
\text { solidarity identity, belief, trust, faith, vision, commitment, } \\
\text { aspiration, worldview, ideology, paradigm }\end{array}$ \\
\hline
\end{tabular}


Oil palm within

national agricultura

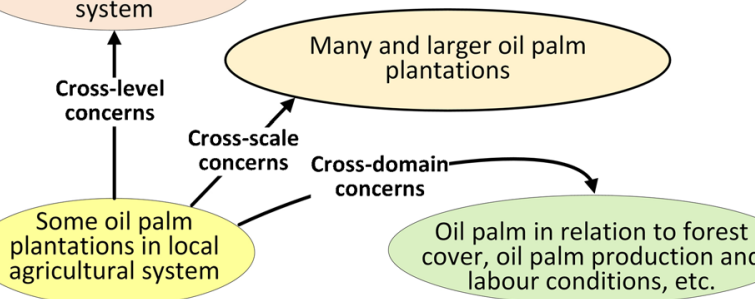

Fig. 5 Scaling processes tend to cross various boundaries - a simple illustration

contexts in a consistent manner. Figure 5 illustrates some of the analytical boundaries that scaling processes tend to cross.

Thus, combining the theory of aspects with the MLP which is focused on levels and scale helps develop an integrative perspective on what exactly may interact and change in relevant practices and systems as novel technologies and practices go to scale. Although technologies, processes, practices and systems function in all aspects, whether part of a niche, regime or landscape, they can be distinguished from one another on the basis of the aspect(s) and its core value that receive prominence in a particular technology, practice, etc. In other words, technologies, processes, practices and systems can be distinguished from each other on the basis of the core value that indicates the very reason of their existence. For agricultural practices, the most prominent feature is usually the efficient application of resources in the production (economic aspect) of goods (food, feed and fuel). In terms of functioning in other aspects, agricultural practices are performed in a particular location (spatial aspect), involve energy (kinematic aspect), involve knowledge (analytical aspect), apply all kinds of technical interventions (formative aspect), involve the use of symbols (including language) to communicate (lingual aspect), have to comply with legislation (juridical aspect), should care about soil fertility and biodiversity (ethical), and so forth. The prevalent conditions regarding all aspects will therefore affect (the performance of) an agricultural practice. For example, a remote location (spatial aspect), little knowledge (analytical aspect) and poor technology (formative aspect) will affect it adversely. Normative perspectives in this context relate to how different people think about how a particular practice is supposed to function in relation to the various aspects.

Technologies, practices and systems are orientated towards a particular purpose: what they are meant to contribute or their reason for existence (the core value of the most prominent aspect). However, subjective choices are involved because actors can decide to perform a practice for their very own reasons. The same applies to systems. A food system may be mainly orientated towards financial benefits (economic aspect) and/or to equitable food distribution (ethical aspect). A mismatch between a (normative) purpose orientation and the actual workings of a system and its outcomes may trigger a feedback loop to adjust the practice or system configuration. For example, agro-ecological niches have emerged because of social movements' dissatisfaction with the dominant farming system (regime) (Duru et al. 2015) that emphasised the importance of one aspect (notably the economic) and forgetting the relevance of others (such as the biotic, social and ethical). Configuration is here understood as the specific way in which a practice or system functions in the various aspects and connects to ideas on dominant designs within regimes.

Applying these ideas on purpose and the values behind them to scaling, in which there is an intentional effort to change regime configurations in several aspects, the classification of a technology or practice as good or not is determined by the extent to which all the core values relating to all the aspects are simultaneously realised (Duru et al. 2015; Lamichhane et al. 2015). For example, the use of pesticides to reduce damage caused by insects may be very efficient (economic aspect) but detrimental to environmental and/or human health conditions (biotic, sensitive, ethical aspect). Also, a new technology may present economic advantages, but be rejected for ecological or ethical reasons.

Figure 6 illustrates this perspective and Fig. 7 shows how this can be applied to the previously mentioned case of rubber cultivation in China.

The theory of aspects framework can therefore help alert researchers and decision makers to the fact that agricultural innovation and scaling generally involve trade-offs, as is already recognised in much work concerning scenario building (e.g. Drott et al. 2013; Schwab et al. 2003; Vervoort et al. 2014). Calls for, e.g. inclusiveness (social aspect) and responsible innovation (ethical aspect) address the observed narrowness of some of the previously criticised approaches to scaling, as discussed in Section 1. The theory of aspects framework can help to make trade-offs in scaling visible. Most scaling initiatives involve a range of interactive scaling processes of which decision makers often only gradually become aware as the initiative unfolds. It resembles a Russian doll

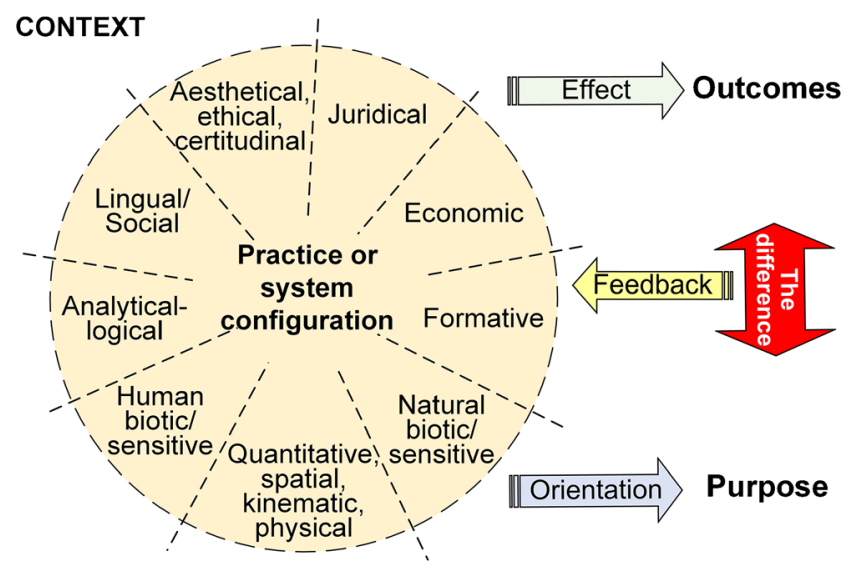

Fig. 6 Creating integrative perspectives on what shapes entities such as practices, systems and institutions 


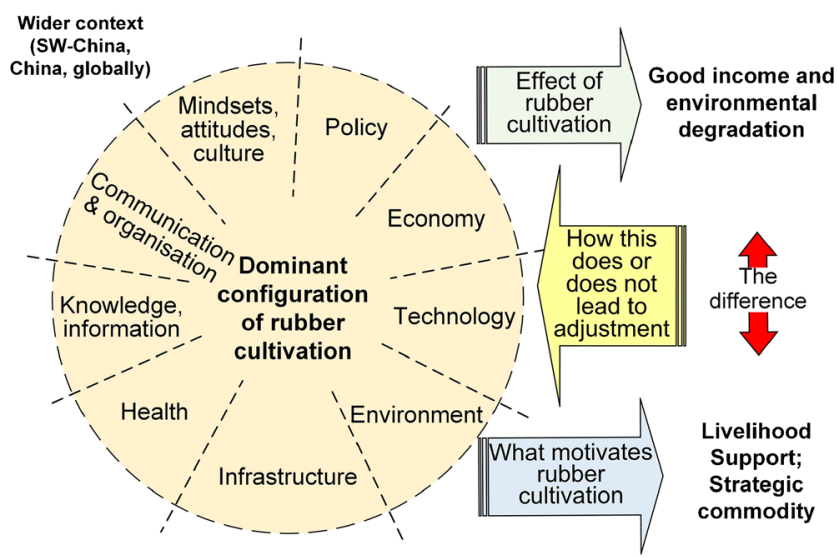

Fig. 7 Localising the integrative perspective. A simplified example in relation to rubber cultivation in SW-China (adapted from Wigboldus et al. forthcoming)

(matryoshka) that continues to produce smaller dolls as it is opened. The theory of aspects framework can help to articulate what concurrent scaling processes and what particular aspects are involved (Table 3).

\subsection{PROMIS as an integrative analytical framework}

In the previous sections, we explained the connection between the MLP and the theory of aspects that highlights the role of practices, and therefore we refer to the resulting integrative framework as the PRactice-Oriented Multi-level perspective on Innovation and Scaling (PROMIS). The multi-level reference relates to how scaling-related changes in practices play out at the landscape, regime and niche levels. The PROMIS framework uses MLP in a flexible way to enhance opportunities for MLP and the theory of aspects to be complementary and to better link to the complexities involved in scaling processes. This also means that the multi-level approach can be used to interpret the ways in which scaling relates to different distinctions between levels, such as local, national and global levels (Schut et al. 2014a, b).

Figure 8 is a simplified illustration of the type of dimensions and dynamics which the PROMIS framework seeks to unpack. Rather than considering a scaling initiative as a singular movement of innovations from niche-level to regimelevel, this perspective suggests the relevance of considering multiple (sub)regimes, contexts and related scaling processes. Taking an innovation to new contexts will expose it to different (types of) dominant systems and practices (regimes). Besides the implications this has for the potential effectiveness of a scaling initiative, it also has implications for potential (lack of) sustainability and opportunities for responsible scaling. The spider-web shapes in Fig. 8 illustrate differences in configuration in relation to the nine aspects.

The PROMIS framework sensitises researchers and policymakers to potentially relevant dimensions and dynamics involved in the complexity of scaling agricultural innovations so as to enrich the spectrum of factors to consider in pursuing effective and responsible scaling. In the next section, we explore a number of ways in which the PROMIS framework can be applied.
Table 3 A scaling initiative often involves a range of interactive scaling processes - an illustration of scaling environmentally friendly rubber cultivation (Wigboldus et al. forthcoming)

\begin{tabular}{ll} 
Aspects of scaling & $\begin{array}{l}\text { What scaling is involved, both in terms of scaling up and scaling } \\
\text { down? }\end{array}$ \\
\hline $\begin{array}{l}\text { Quantitative (more/less) } \\
\text { Spatial (more or less spread) }\end{array}$ & More farmers involved \\
Kinematic (faster, more mobile) & Zoning of rubber cultivation plots \\
& $\begin{array}{l}\text { Faster dissemination of knowledge about more environmentally } \\
\text { friendly practices }\end{array}$ \\
Physical (bigger, more encompassing) & Larger project needed to support this \\
Biotic/sensitive (non-human) & Diversification of cash crops \\
Biotic/sensitive (human) & Reducing health effects resulting from use of pesticides \\
Analytical-logical & Increasing knowledge about alternative crops and livelihood \\
& opportunities \\
Cultural-formative & Wider adoption of new practices; adaptation of cultivation plans \\
Lingual and social & Increasing communication and collaboration between researchers \\
& and farmers \\
Economic & Wider adoption of new business models \\
Juridical & New policies and legislation stimulating scaling of \\
& environmentally friendly rubber \\
Aesthetic & Landscape beautification through reduced impact of rubber \\
plantations
\end{tabular}


Fig. 8 Enriching perspectives on scaling processes by identifying potentially relevant dimensions and dynamics - a simplified perspective

\section{Enriching perspectives on scaling processes by applying the PROMIS framework}

In this section, we discuss how the PROMIS framework can be applied towards (Section 3.1) analysing the context in which scaling takes place and that it intends to change (regime), (Section 3.2) anticipating the regime changes that the scaling effort may produce, (Section 3.3) understanding how different stakeholders feature in scaling, and (Section 3.4) supporting stakeholders in the future-oriented positioning of scaling initiatives. In the four subsections we suggest ways in which complexities involved in scaling processes may be explored from different angles.

\subsection{Analysing the regime configuration in which scaling takes place}

In this section, we focus on the notion of dominance and deviance, and on stability and rigidity factors involved in regime configurations that are of importance because they determine the context and point of departure for scaling. Dominance of the regime in terms of incumbent and dominant technologies and practices, and deviance of novel technologies and practices, can be interpreted in relation to actors and factors that can be characterised in relation to the suite of aspects. Dominance as well as deviance may, for example, relate to people's aspirations (aesthetical, ethical, certitudinal aspect) or to the dominant use of certain technologies (formative aspect). It may also relate to powerful actors such as industry (economic actor) or government (juridical actor). Or it may relate to formal and informal institutions, such as legal frameworks (juridical aspect) or associations (social aspect). This may involve power issues (Avelino and Rotmans 2009; Geels 2014; Olsson et al. 2014). The way in which powerful actors exert influence over the way practices/systems are (re)configured may be characterised along the lines of the suite of aspects. This may involve binding contracts (juridical aspect) or lack of access to credit facilities (economic aspect). Analysis may 'locate' where, i.e. in relation to which aspect/ aspects, a niche innovation and the relevant regime are different, non-aligned or in conflict. This clarifies which aspects will need to be considered in scaling.

Routine and stability are to a certain extent desirable features of practices and systems, or in other words, of regimes. Regime stability facilitates fine-tuning and an evolving excellence in performance. Societies require stability for individuals and relationships to thrive. At the same time, they need to adapt to new conditions, capitalise on new opportunities, meet newly defined purposes or counteract adverse effects of the practice/system. In other words, regime configurations (practices and technologies) are dynamically stable (Geels 2002). As discussed in Section 2, configurations at any level may become locked into a status quo because of rigidity with respect to any aspect, and hence prevent transitions to desired situations: for example, more inclusiveness, sustainability, and diversity of agricultural systems (Elzen et al. 2012; Horlings and Marsden 2011; Stirling 2009, 2011). In terms of scaling, path dependence can be of influence in different ways. One way is through social issues such as resentment over collaboration between stakeholders in the past; another way is through biophysical conditions, for example whether a plot of land has been well-fertilised in the past or hardly fertilised 
at all over the years, which will affect this year's crop performance (Giller et al. 2011). Given that here people's behaviour is a key element in creating and perpetuating path dependence, the concept of imprinting describes how organisations take on elements of their original/previous environment and how these elements persist (Marquis and Tilcsik 2013). Similar ideas have been proposed in socio-psychological studies (e.g. Bar-Tal 2013), referring to people's histories and how their current actions may not connect to current (context) conditions, but to what they experienced in the past. Path dependence and organisational imprinting can also be understood in terms of ceilings (not allowing further expansion), as discussed by IIRR (1999) and Röling $(2009,2011)$ in relation to institutions and institutional development.

The suite of aspects helps to unpack types of path dependence and imprinting that are relevant for scaling initiatives. These may relate to such different issues as soil depletion (the kinematic/physical aspect), farmers' apathy due to a history of restrictive political regimes (sensitive aspect) and an attitude of indifference (ethical aspect) because people have become used to seeing forests disappear or labourers being exploited. The suite of aspects can help identify so-called lock-ins that may affect scaling, such as for example:

- Formative lock-in, e.g. because dominant use of a particular technology or set of technologies, such as external fertilisers, ploughing and combinations of genetically manipulated seeds and specific herbicides, stipulates what the cropping system looks like

- Juridical lock-in, e.g. because a particular regulation (e.g. ban on GMOs) limits choice options

- Economic lock-in, e.g. because detrimental practices (e.g. use of pesticides) provide private returns in the short run but have negative spill-overs that tend to affect public goods

- Physical/biotic lock-in, e.g. because climate change or soil depletion limits farming options

The need for adaptation and change - and hence innovation in technologies, practices and systems - often relates to stress, which is gradual, and to shock, which is sudden and relates to short-life-span events. Stress and shock relate to what is called the landscape in the MLP, and, as they may induce innovations, they may also be seen as windows of opportunity (Elzen et al. 2012; Geels 2011). A distinction can be made between different types of stress and shock, which can be characterised in relation to the suite of aspects (Table 4). Stress can be ecological, psychological, social, economic and so on. The various stresses and shocks interact: stress or shock in relation to one aspect may trigger a reaction in relation to other aspects. In a systemic perspective, scaling up a novel technology or practice may solve or address a particular stress/shock, while aggravating or introducing other stress/shock factors. Some of these stresses and shocks may relate to power dynamics. An example of this is a powerful company requiring changes in agricultural practices to comply with company standards. Understanding how an envisaged scaling initiative connects to such stress and shock factors can help decision makers to identify appropriate scaling strategies.

\subsection{Strategic analysis of anticipated scaling dynamics}

In this section, we explore a selection of considerations that we consider to be of particular relevance in strategically positioning a scaling initiative. Metaphorically speaking, a regime may be considered as a kind of iron dome that needs to crack open to allow for an influx (scaling) of novel technologies and practices (push approach). The regime may also be perceived as a magnet that stimulates the emergence of appropriate novel technologies and practices (pull approach) which are in line with (emerging) purpose (re)orientations. Depending on situation specificities, different innovation and scaling approaches and related policies and interventions can therefore be considered. Figure 9 illustrates this.

The first approach (push) takes for granted the value of the technology or practice (e.g. higher yielding crop variety) to be scaled up and focuses on uptake and adoption. The second approach (pull) sets a benchmark (vision) for what innovation and associated scaling processes need to contribute and connect to, and focuses on reorienting system values towards this, i.e. some players such as policymakers within the regime may assist niches to make changes and disrupt the regime (Alrøe and Kristensen 2002; Kivimaa and Kern 2016; Mitchell et al. 2015). For example, a sector policy regarding sustainable energy may stimulate the scaling of new sustainable energy technologies through tax exemptions and subsidies. MLP was developed mainly to understand processes involved in radical innovation and scaling (push), and developing related management approaches such as strategic niche management. It is important to expand views on scaling to prevent a sole focus on 'pushed scaling' (make things go to scale by supporting niche expansion), whereas 'pulled scaling' (help things go to scale by changing regime conditions) may in fact be a much more common (and often more appropriate and effective) approach. However, the latter approach is not often thought of sufficiently when a scaling initiative is being considered (Geels 2014; Kivimaa and Kern 2016). Our literature review thus leads us to conclude that scaling agricultural innovations (novel technologies and practices) is generally understood as a process of making agricultural innovations go to scale through a push approach. This limits the scope of strategic options considered, in line with the previously discussed criticisms on dissemination and diffusion approaches. Hence, the development of systemic perspectives needs to translate into a variety of strategic options for engaging with system dynamics at both niche and regime level. The use of systemic perspectives will be of little use if the 
Table 4 Examples of internal and external stresses and shocks in relation to changing practice/ system configurations

\begin{tabular}{ll} 
Type of stress/shock & Unpacking through the suite of aspects \\
\hline Incompatibility issues & $\begin{array}{r}\text { A new cultivation plan (analytical aspect) does not take into consideration the } \\
\text { specific requirements of a particular (hybrid) crop such as increased fertiliser } \\
\text { use (kinematic/physical aspect) or training (analytical aspect) } \\
\text { Poor access to rights (juridical aspect), services (formative aspect), resources } \\
\text { (physical/biotic aspect), or knowledge (analytical aspect) can limit potential } \\
\text { functionality of practices/system }\end{array}$ \\
Access issues & $\begin{array}{l}\text { A particular cropping system does not provide the level of income (economic } \\
\text { aspect) anticipated/hoped for } \\
\text { Climate change and severe weather conditions (kinematic/physical aspect), } \\
\text { financial market crisis (economic aspect), changing government regulations } \\
\text { (juridical aspect), etc., put pressure on agricultural practices and system } \\
\text { Value-based opposition (ethical/certitudinal aspect) to the use of a particular } \\
\text { technologies such as GMOs (formative aspect) in a sector }\end{array}$ \\
Value issues &
\end{tabular}

mode of engaging with complexity is rather singular. In terms of considering such complexity, and building on the idea of push scaling, pull scaling and interventions, it is relevant to consider that some scaling processes are actively pursued but many happen anyway, without being actively pursued. Scaling processes are part of nature and society, and they happen constantly with and without deliberate action. For example, weeds and pests go to scale without anyone putting a conscious effort into making this happen. Any envisaged scaling initiative will need to be positioned within the bigger picture of wider scaling processes (including landscape trends). Scaling initiatives may also trigger new scaling processes. The wider application of a particular crop variety and planting it as a monoculture may trigger the scaling of certain pests and diseases. Also, scaling up the application of one particular practice will often involve or even require the scaling down of other practices. It may further require associated scaling processes such as scaling up the application of specific knowledge to enable a new practice to be performed properly. Figure 10 illustrates how it is often necessary to position a scaling initiative within such wider dynamics of ongoing and emerging scaling processes and related trends and developments.

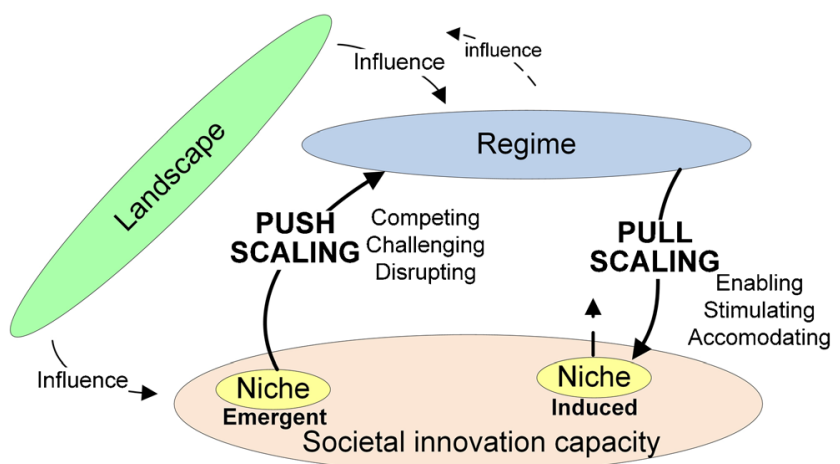

Fig. 9 Distinguishing between different types of scaling initiatives in a simplified MLP view

\subsection{Understanding different stakeholders' roles in scaling}

Scaling processes involve a range of stakeholders related to both niches and regimes. The suite of aspects can be used in a number of ways to develop a systematic understanding of these stakeholders. Firstly, the aspects can be used to distinguish between types of stakeholders who are involved in terms of what aspect characterises their core practices, and hence their interests. This may prevent an undue focus on particular objectives of scaling, related to, for example, economic interests. Secondly, the aspects can be used to characterise the core motivations (or purpose orientations) of stakeholders in terms of what drives stakeholders' decision making. This may, for instance, be technology-driven (emphasis on the formative), market-driven (emphasis on the economic), policy-driven (emphasis on the juridical) or service-driven (emphasis on the ethical). Although usually less pronouncedly, it will often also reflect individual and group identity, style and preference (relating to aesthetical, ethical and certitudinal aspects) where, for example, farmers' choices relate to more

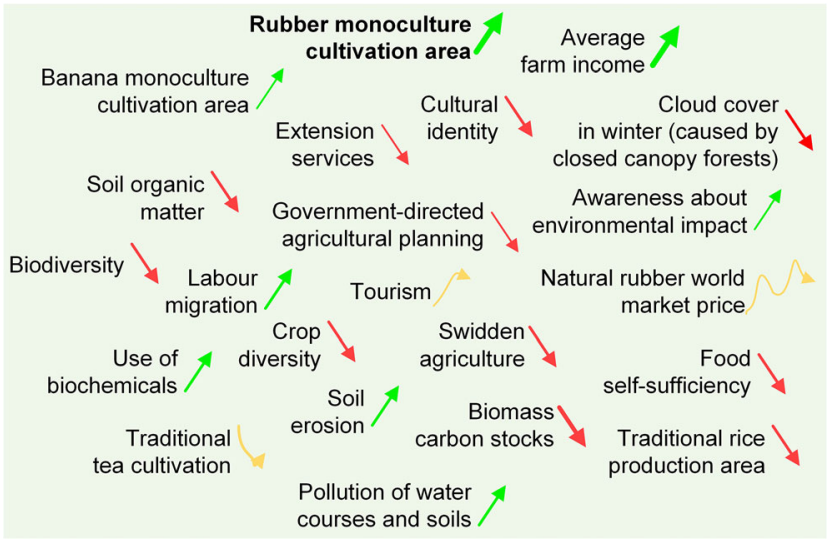

Fig. 10 Positioning scaling initiatives in a context of simultaneously occurring scaling processes. Example of scaling environmentally friendly rubber practice in SW-China (adapted from Leeuwis and Wigboldus, forthcoming) 
than rational optimisation of assets and utility maximisation (e.g. Bell et al. 2004; van der Ploeg 1993). Thirdly, the suite of aspects may be used to identify the variety of ways in which practices, systems, and their effects are evaluated by stakeholders. This includes understanding how comprehensive their views of effects are: they may not be aware of, or not pay attention to, certain effects that relate to particular aspects, and hence may not be able to negotiate convergence in multistakeholder processes (Leeuwis 2000).

Stakeholder dynamics play out at different levels of decision making and governance. Decision making in relation to a single practice (e.g. a cultivation task) is to a certain extent determined in a limiting or facilitating way by how the farming system as a whole is governed, and we may characterise this interaction along the lines of the suite of aspects. The same goes for the relationship between a farming system and the wider agricultural sector or value chain and policy and regulatory system in which the farming system is embedded. The PROMIS framework can thus be used to organise an overview of actor perspectives in the light of an envisaged scaling initiative, such as in terms of what different stakeholders think are the most important/relevant aspects to be considered in the initiative. It may also be used to consider how this initiative may affect stakeholders in different ways, such as in relation to gender and diversity issues (children, physically challenged people, minority groups, social classes) or in relation to power issues regarding who/what drives or benefits from the scaling initiative (Bailey 2011; Leach et al. 2010; Melber 2012; Stirling 2009, 2011).

\subsection{Supporting stakeholders in future-oriented analysis of scaling}

As regards the ultimate potential of technologies, scaling processes may set things in motion in a way that was not fully anticipated, in terms of both positive effects (Geels 2001) and negative effects (Gee et al. 2013), as highlighted in Section 1. The suite of aspects can inform foresight exercises, which activate cross-temporal perspectives, so that the scope of, e.g. scenario analysis will be appropriately inclusive (e.g. Barakatt et al. 2010; Foresight 2011; Nelson et al. 2010; Paillard et al. 2014; Vervoort et al. 2014).

While scaling processes originate from within particular system and domain boundaries (e.g. cropping system, value chain, sector), they tend to affect, and be affected by, factors that lie beyond the boundaries of the systems, domains and levels that are the focus of a scaling initiative (Fig. 10), and thus involve and impact stakeholders at different scales and levels in systems. This involves all kinds of complexities. What is good from a private-sector perspective (private goods) will not necessarily be considered good from a public-sector perspective (public goods). Also, scaling may result in a growing disconnect between purpose orientations and outcomes (van der Ploeg 2006), such as farmers losing sight of the effects of pesticide use if they no longer eat (some of) their own produce when they become market oriented. Similarly, a sector, value chain or multinational may not incorporate effects of scaling up the application of certain products, processes, or practices in its decision making because negative effects take place in another domain (e.g. the environment or health) and/or another geographical area (Milder et al. 2014; Sayer et al. 2014). Finally, from, e.g. a sector perspective, scaling can be considered to have positive impact, but it may not work out well for all groups and individuals in it, which points to the need for inclusive perspectives on scaling.

This calls for activating cross-scale and cross-domain perspectives (Yu et al. 2012) in scaling, making use of existing information relating to different scales and bringing together researchers, stakeholders and decision makers from across levels and domains (Borgström et al. 2006; Cash et al. 2006; Cumming et al. 2006, 2012; Loveridge 2009; Padt et al. 2014) to inform responsible scaling by anticipating undesired effects or unintended effects at scales, levels and domains that are not supposed to be affected by the scaling effort. Foresight exercises through scenario analysis can enrich the theories of change that are commonly articulated for scaling initiatives (e.g. Adekunle and Fatunbi 2014; Arkesteijn et al. 2015).

Applying foresight approaches to the context of scaling thus involves scenario analysis addressing the question 'what if this goes to scale?' For example, such analysis may involve anticipating what a wider application of a particular cropping system would mean for markets (economic aspect), the environment and nutrition (physical and biotic aspect); how it might interact with wider technological trends and developments (formative aspect) and how it would connect to societal concerns (aesthetical, ethical, certitudinal aspect). Foresight exercises and scenario analysis may involve risk and trade-off analysis (e.g. Guillem et al. 2015; Komarek et al. 2015) and social and environmental impact assessment, or be supported by participatory modelling and companion modelling in which stakeholders are included as active participants (Bousquet et al. 2005; Delmotte et al. 2013; Gouttenoire et al. 2013; Sandker et al. 2010). Foresight exercises may be guided by the suite of aspects articulated in the PROMIS framework, which also can be used as a checklist to consider what kinds of assumptions underpin envisaged scaling initiatives, or to consider in modelling exercises what must be part of the model and in what way.

\section{Using the PROMIS framework as an integrative tool in research: early experiences}

In Sections 2 and 3, we explored opportunities for enriching perspectives on scaling processes. Table 5 illustrates how different elements, discussed in those sections, can be combined towards creating an integrative perspective on a particular 
Table 5 Developing integrative perspectives on scaling initiatives

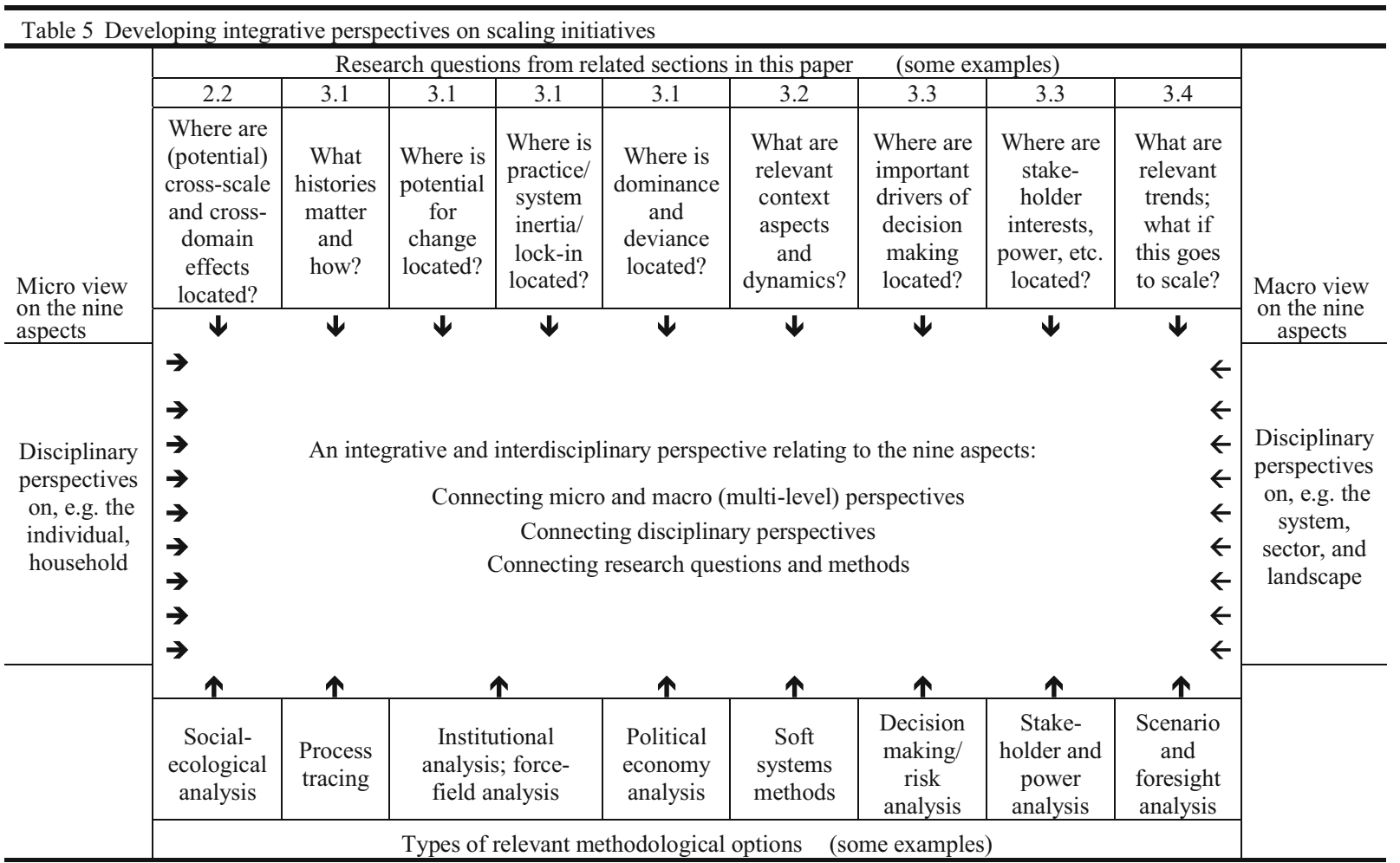

scaling initiative while indicating the type of analytical tools that may be used for this. The columns relate to the topics explored in Sections 2 and 3. These are summary descriptions and do not reflect the full scope of possible questions to guide analysis.

The variety of suggested methodological options follows pleas to use mixed methods and mixed approaches for research and evaluation (Johnson and Onwuegbuzie 2004; Garcia and Zazueta 2015) in order to enrich perspectives and to compensate for limitations of particular methods and approaches. Single actors will rarely have a complete view of, let alone a mandate and/or control over, the multi-faceted dimensions and dynamics involved in agricultural scaling processes. As Table 5 shows, the PROMIS framework can help in determining the use of an appropriate mix of methods and approaches for coherent analysis, depending on the several questions to be addressed, and hence support interdisciplinary analysis and integrated policy making.

However, in many cases, it will not be feasible nor even desirable to apply the fully-fledged integrative perspective on each scaling initiative as presented in Table 5 . On the basis of existing knowledge and estimated risk levels involved, a selection of initial focus points and research methods connected to these can be made (e.g. zooming in on variations in what informs farmer decision making). This appears a contradiction, as the PROMIS framework is intended to broaden perspectives on scaling. When the use of the PROMIS framework is being tailored to a particular situation, appropriate and feasible levels of comprehensiveness of analysis need to be decided on. However, the PROMIS framework can serve here to elucidate relevant issues that were originally not considered by the scaling effort. Also, an initial wide-ranging assessment may be done in the form of a quick-scan study, after which a more focused analysis can be conducted in relation to selected aspects that are deemed most pertinent. So far, we have operationalised the PROMIS framework in three different case studies involving three different application approaches (see Table 6).

The first two studies provided input into strategy development for the envisaged scaling initiative regarding both the range of interactive factors and dynamics that would need to be taken into account and stakeholders' perspectives on how this could be done. The third study identified key reasons for the scaling initiative's disappointing outcomes at individual and systems level, including relevant learning for other scaling initiatives. By applying an uncommonly broad perspective on dimensions and dynamics involved in scaling processes, the PROMIS framework helped to identify important clues that other analytical approaches tend to miss because they explore within a particular domain of change only. This includes providing a framework for considering what makes for responsible scaling. 
Table 6 Initial operationalisation of the PROMIS approach in three cases

Case 1: An exploratory study on scaling up environmentally friendly rubber practice in SW-China (Wigboldus et al. forthcoming).

Application of the PROMIS approach by using:

- The framework to focus a literature study so as to identify how the relevant range of factors and related dynamics affect opportunities for making rubber cultivation environmentally friendly

- The framework to consider how stakeholders relate to particular aspects and to decide whose perspectives and roles would be particularly important to take into account

- The framework to develop a semi-structured questionnaire in relation to pertinent issues and to ask a range of informants to score pertinent issues (relating to the aspects) in terms of relevance, of what locks in current rubber cultivation practice, and of what creates opportunities for change (results were expressed in a spider diagram to create an overview and allow for quick comparison)

- Soft systems methodology (rich picture) in interactive stakeholder processes to reflect on the integrated nature of issues (Checkland and Scholes 1999)

- The resulting overview to consider what would need to be addressed and how, and who should be involved in what way if the objective was to scale up environmentally friendly rubber practice

Case 2: Providing a broad systemic perspective on factors involved in scaling up agro-ecology practice in Nicaragua while focusing on household-level decision making within that bigger picture

Application of the PROMIS approach by using:

- Similar elements as the above, but then in relation to multiple workshops and wider consultation with stakeholders

- Using additional household-level surveys in which questions derived from the value-belief-norm theory (e.g. Stern 2000) were used to assess decision-making processes

- Connecting macro (bigger picture) perspectives with micro (farmer decision making) perspectives to create a multi-dimensional framework for decision making.

Case 3: Guiding retrospective analysis of a scaling initiative: a study on the scaling and institutionalisation of cocoa farmer field schools in Cameroon (Muilerman et al. forthcoming)

The study involved the development of a narrative description, both chronologically and along the lines of MLP. This narrative description was subsequently analysed in relation to a PROMIS perspective in two ways:

- In terms of the extent to which aspects played a specific role in the disappointing outcomes of the scaling iniative

- In terms of what dynamics played what role in the disappointing outcomes of the scaling initiative by considering the dynamics as discussed in Section 3 of this paper

We can illustrate this in the case of green rubber: research findings pointed, among others, to the need to broaden perspectives on what is involved in scaling 'green rubber' practice from a dominant focus on exploring 'technical' options (e.g. adapting/diversifying rubber cropping system), to the inclusion of the role of institutional and paradigmatic constraints and opportunities. The findings also highlighted the need to consider required changes in rubber cultivation in a wider landscape perspective to prevent shifting problems from rubber to those caused by, e.g. the scaling of banana cultivation.

These two examples highlight that applying the PROMIS framework indeed enables a richer perspective on scaling; however, further development of PROMIS to serve as a research tool is needed as we will discuss in the next section.

\section{Conclusion: current contribution of PROMIS and next steps}

At the start of this paper, we argued that common approaches to scaling, using concepts such as dissemination, diffusion, adoption and transfer of technologies and practices, are not sufficient to grasp the complexities involved in scaling processes. As a result, decision makers often do not have a sufficiently broad picture of what they need to prepare for, and engage with, in scaling initiatives. This limits policies, strategies and guidance of scaling initiatives from becoming both effective and responsible in the light of societal values and aspirations.

We seek to contribute to addressing this gap by introducing PROMIS as an integrative analytical framework that can contribute to the heuristic exploration of relevant dimensions and dynamics involved in innovation and scaling processes. The PROMIS framework raises awareness about the multi-faceted dimensions and dynamics to be considered in scaling initiatives. The underlying systemic frameworks (MLP and the theory of aspects) provide a coherent reference framework that can be made operational through application of specific methods and methodologies. The PROMIS framework can help in appropriately informing scaling initiatives in the light of core dimensions of responsible innovation: being anticipatory, responsive, inclusive and reflexive. We may therefore consider the PROMIS framework to support a capability for responsible innovation and scaling.

In projects which include a clear scaling ambition, operational theories of change rarely include an articulated 'theory of scaling' (how scaling is expected to happen) nor a clear perspective on 'what if this goes to scale?' (including potential negative implications of particular innovations going to scale). This thus goes beyond installing mechanisms which may foster scaling by establishing enabling conditions for scaling such as local adaptation processes (Millar and Connell 2010), and innovation platforms working on a match between technologies and a conducive institutional and market environment (Kilelu et al. 2013) or diffusion mechanisms such as mobile phone based information services (Aker 2011; Baumüller 2016). It would be about defining such a theory of scaling in a systematic way (see Wigboldus et al. forthcoming). The PROMIS framework can help in drawing up such a theory of scaling by alerting those who have primary responsibilities in design and management of such initiatives by helping to address strategic questions such as:

Do we need to be more critical about this scaling initiative, for example regarding who really benefits or what potentially negative effects at scale may result? This relates to dimensions 
of responsible innovation and scaling, and perspectives on sustainability, beyond seeking technical 'fixes' (Brandon and Lombardi 2011). It also relates to debates regarding the role of diversity and how scaling initiatives may reduce this, thus allegedly leading to increased vulnerability (Leach et al. 2012).

Do we need to be more creative in devising scaling strategies? We may, for example, need to choose to focus more on creating conditions for scaling rather than on actively trying to make something go to scale (Leeuwis and Aarts 2012; Westley et al. 2014; Wigboldus and Leeuwis 2013). It may also involve considering a range of potential leverage points (entry points) in terms of places to intervene in systems (Meadows 2009). This may, for example, lead to the adjustment or broadening of a strategy from a focus on scaling new cultivation practices, to addressing organisational and institutional prerequisites for sustainability.

Do we need to be more co-creative in the scaling initiative? This may require the forging of supportive partnerships (Aldrich 2011; Bhawnick 2015; Faustino and Booth 2014; GEO 2011; Klein Woolthuis 2013), such as innovation platforms, networks or labs (e.g. Kieboom 2014; Kilelu et al. 2013; Schut et al. 2015a, b; Tenywa et al. 2011; Unicef 2012). Initiatives such as SUN (http://scalingupnutrition. org/) and GAIN (http://www.gainhealth.org/) are good examples of collaborative scaling initiatives.

Do researchers need new competencies to engage effectively and responsibly with scaling processes? Disciplinary research is often well-equipped to highlight tensions between functions within an aspect. For example, agronomic research can assess whether a new hybrid may perform well in terms of soil, not so good in relation to pathogens, better in relation to climate, and so on. In scaling, however, new concerns open up that need to be explored, but that often fall outside the scope of such more focused research. This means that it will often become much more than an agronomic innovation and scaling process, requiring broader expertise and competencies. We would therefore argue that a process of innovation and scaling has to be approached as an interdisciplinary or transdisciplinary endeavour. This may also involve new roles for researchers, combining an expert role with a role of facilitating collaborative processes (Brouwer and Woodhill 2015; Hermans et al. 2013; Schut et al. 2011; Spruijt et al. 2014; Turnhout et al. 2013; Wittmayer and Schäpke 2014), and this will also require that an enabling environment is created as existing procedures, incentive systems and funding mechanisms may work against such new roles (Roux et al. 2010; Turner et al. 2016).

Initial applications of the PROMIS framework in research created awareness about, and helped to unpack, complexities involved in scaling initiatives. One of the case studies demonstrated how a resulting integrative perspective can inform scaling strategies, and another case study showed how the
PROMIS framework can be used in the retrospective analysis of a scaling initiative.

In this paper, we sketched the contours of an integrative framework to enrich perspectives on and analysis of scaling processes and discussed initial empirical testing. However, experiences with the PROMIS framework as a research tool are tentative, and we invite scholars to further develop it, since as the framework is tentative, it needs further grounding. Further research may pursue two directions: further elaboration of the PROMIS framework to strengthen its conceptual grounding (e.g. in relation to the interactions between aspects), and further field testing and refining to make it more suitable for providing practical research and decision-making support. More research is needed to validate the analytical lenses within the PROMIS framework and underpin it with empirical studies. Also, further development of more precise indicators and criteria is needed to measure the several aspects of scaling, as well as to measure their interrelationships, causalities and possible synergies and emergent effects.

From a practical perspective, policymakers in particular would benefit from the further development of the PROMIS framework into a reflexive decision support tool to guide responsible innovation and scaling. This would include development of a methodological approach on how to articulate a theory of scaling (assumptions regarding how scaling is expected to happen) to guide decision makers in (innovation) projects that have a clear scaling ambition. The challenge and perhaps trade-off and tension in such follow up work will be not to lose the holistic perspectives of PROMIS and in effect go back to single discipline oriented, reductionist ways of analysing scaling processes.

Acknowledgments This research was supported by the CGIAR Research Program on Integrated Systems for the Humid Tropics (Humidtropics). We would like to acknowledge Humidtropics and the CGIAR Fund Donors for their provision of core funding without which this research would not have been possible. The International Centre for Tropical Agriculture (CIAT) in Nicaragua and the World Agroforestry Centre (ICRAF) in China were active hosts of case studies that used the PROMIS framework to structure research. We also thank Onno Giller and Katharina Schiller for experimenting with an earlier version of PROMIS in field research.

Open Access This article is distributed under the terms of the Creative Commons Attribution 4.0 International License (http:// creativecommons.org/licenses/by/4.0/), which permits unrestricted use, distribution, and reproduction in any medium, provided you give appropriate credit to the original author(s) and the source, provide a link to the Creative Commons license, and indicate if changes were made.

\section{References}

Abebawa D, Haile MG (2013) The impact of cooperatives on agricultural technology adoption: empirical evidence from Ethiopia. Food Policy 38:82-91. doi:10.1016/j.foodpol.2012.10.003 
Adekunle AA, Fatunbi AO (2014) A new theory of change in African agriculture. Middle-East J Sci Res 21:1083-1096. doi:10.5829/idosi.mejsr.2014.21.07.21564

Aguilar-Gallegos N, Muñoz-Rodríguez M, Santoyo-Cortés H, AguilarÁvila J, Klerkx L (2015) Information networks that generate economic value: a study on clusters of adopters of new or improved technologies and practices among oil palm growers in Mexico. Agric Syst 135:122-132. doi:10.1016/j.agsy.2015.01.003

Aker JC (2011) Dial "a" for agriculture: a review of information and communication technologies for agricultural extension in developing countries. Agric Econ 42:631-647. doi:10.1111/j.15740862.2011.00545.x

Aldrich HE (2011) Heroes, villains, and fools: institutional entrepreneurship, NOT institutional entrepreneurs. Entrep Res J 1:1-6. doi:10.2202/2157-5665.1024

Alrøe HF, Kristensen ES (2002) Towards a systemic research methodology in agriculture: rethinking the role of values in science. Agric Hum Values 19:3-23. doi:10.1023/A:1015040009300

Anderson I (2012) Scaling development results. A literature review and implications for Australia's aid program. AusAid, Canberra

Arkesteijn M, van Mierlo B, Leeuwis C (2015) The need for reflexive evaluation approaches in development cooperation. Evaluation 21: 99-115. doi:10.1177/1356389014564719

Ashby A, Leat M, Hudson-Smith M (2012) Making connections: a review of supply chain management and sustainability literature. Int J Supply Chain Manag 17:497-516. doi:10.1108 $/ 13598541211258573$

Avelino F, Rotmans J (2009) Power in transition: an interdisciplinary framework to study power in relation to structural change. Eur J Soc Theory 12:543-569. doi:10.1177/1368431009349830

Avelino F, Wittmayer JM (2015) Shifting power relations in sustainability transitions: a multi-actor perspective. J Environ Pol Plan, 1-22. doi:10.1080/1523908X.2015.1112259

Bailey R (2011) Growing for a better future. Food justice in a resourceconstrained world. Oxfam International, Oxford

Barakatt C, Burlando A, Kariuki JG, Najam A, Sereke-Brhan H (eds) (2010) Africa 2060: good news from Africa. A report of the Pardee Center Conference Africa 2060: good news from Africa held on April 16, 2010. Boston University, Boston

Bar-Tal D (2013) Intractable conflicts. Socio-psychological foundations and dynamics. Cambridge University Press, New York

Basden A (2008) Philosophical frameworks for understanding information systems. IGI Global, Hershey, PA and London

Basden A (2015) Dooyeweerd's theory of aspects http://kgsvr. net/dooy/asp.html. Accessed 7 October 2015

Baumüller H (2016) Agricultural service delivery through mobile phones: local innovation and technological opportunities in Kenya. In: Gatzweiler WF, von Braun J (eds) Technological and institutional innovations for marginalized smallholders in agricultural development. Springer International Publishing, Cham, pp. 143-162

Bebbington A (1999) Capitals and capabilities: a framework for analyzing peasant viability. Rural livelihoods and poverty. World Dev 27: 2021-2044. doi:10.1016/S0305-750X(99)00104-7

Bell MM, Jarnagin S, Peter G, Bauer D (2004) Farming for us all: practical agriculture and the cultivation of sustainability. The Pennsylvania State University Press, Pennsylvania

Berkes R, Folke C (1992) A systems perspective on the interrelations between natural, human-made and cultural capital. Ecol Econ 5:18. doi:10.1016/0921-8009(92)90017-M

Bhawnick S (2015) They look while they leap: generative co-occurrence of enactment and effectuation in entrepreneurial action. J Manag Organ FirstView:1-20. doi:10.1017/jmo.2014.81

Blesh J, Wolf S (2014) Transitions to agroecological farming systems in the Mississippi River Basin: toward an integrated socioecological analysis. Agric Hum Values 31:621-6e35. doi:10.1007/s10460014-9517-3
Borgström ST, Elmqvist T, Angelstam P, Alfsen-Norodom C (2006) Scale mismatches in management of urban landscapes. Ecol Soc 11:16 [online] URL: http://www.ecologyandsociety.org/vol11/iss2/art16/

Bousquet F, Trébuil G, Hardy B (eds) (2005) Companion modeling and multi-agent systems for integrated natural resource management in Asia. International Rice Research Institute, Los Baños

Brandon P, Lombardi P (2011) Evaluating sustainable development in the built environment, 2nd edn. Wiley-Blackwell, Chichester

Brandt P (2013) A review of transdisciplinary research in sustainability science. Ecol Econ 92:1-15. doi:10.1016/j.ecolecon.2013.04.008

Brouwer H, Woodhill J (2015) The MSP guide. How to design and facilitate multi-stakeholder partnerships. Centre for Development Innovation, Wageningen UR, Wageningen

Cash DW, Adger WN, Berkes F, et al. (2006) Scale and cross-scale dynamics: governance and information in a multilevel world. Ecol Soc 11:181192 [online] URL: http://www.ecologyandsociety.org/vol11/iss2/art8/

Castro P, Hörnlein L, Michaelowa K (2014) Constructed peer groups and path dependence in international organizations: the case of the international climate change negotiations. Glob Environ Chang 25:109120. doi:10.1016/j.gloenvcha.2014.01.007

Cerf M, Jeuffroy M-H, Prost L, Meynard J-M (2012) Participatory design of agricultural decision support tools: taking account of the use situations. Agron Sustain Dev 32:899-910. doi:10.1007/s13593-0120091-Z

Checkland P, Scholes J (1999) Soft systems methodology in action. Wiley, Chichester

Clark CH, Massarsky CW, Schweitzer Raben T, Worsham E (2012) Scaling social impact. A literature toolkit for funders. Growth Philanthropy Network and Duke University, Durham

Coe R, Sinclair F, Barrios E (2014) Scaling up agroforestry requires research 'in' rather than 'for' development. Curr Opin Environ Sustain 6:73-77. doi:10.1016/j.cosust.2013.10.013

Cumming GS, Cumming DHM, Redman CL (2006) Scale mismatches in social-ecological systems: causes, consequences, and solutions. Ecol Soc 11:14 [online] URL: http://www.ecologyandsociety. org/vol11/iss1/art14/

Cumming GS, Olsson P, Chapin FS, Holling CS (2012) Resilience, experimentation, and scale mismatches in social-ecological landscapes. Landsc Ecol 28:1139-1150. doi:10.5751/ES-06799-190401

Dalgaard T, Hutchings NJ, Porter JR (2003) Agroecology, scaling, and interdisciplinarity. Agric Ecosyst Environ 100:39-51. doi:10.1016/S0167-8809(03)00152-X

Darnhofer I, Lindenthal T, Bartel-Kratochvil R, Zollitsch W (2010) Conventionalisation of organic farming practices: from structural criteria towards an assessment based on organic principles. A review. Agron Sustain Dev 30:67-81. doi:10.1051/agro/2009011

Delmotte S, Lopez-Ridaura S, Barbier JM, Wery J (2013) Prospective and participatory integrated assessment of agricultural systems from farm to regional scales: comparison of three modeling approaches. J Environ Manag 129:493-502. doi:10.1016/j.jenvman.2013.08.001

Diaz M, Darnhofer I, Darrot C, Beuret JE (2013) Green tides in Brittany: what can we learn about niche-regime interactions? Environ Innov Soc Transit 8:62-75. doi:10.1016/j.eist.2013.04.002

Dibba L, Diagne A, Fialor SC, Nimoh F (2012) Diffusion and adoption of new rice varieties for Africa (Nerica) in the Gambia. Afr Crop Sci J 20:141-153

Douthwaite B, De Haan N, Manyong VM, Keatinge JDH (2001) Blending "hard" and "soft" science: the "follow-the-technology" approach to catalyzing and evaluating technology change. Conserv Ecol 5(2):13

Drott L, Jochum L, Lange F, Skierka I, Vach J, van Asselt MBA (2013) Accountability and risk governance: a scenario-informed reflection on European regulation of GMOs. J Risk Res 16:1123-1140. doi:10.1080/13669877.2012.743161

Duru MD, Therond O, Fares M (2015) Designing agroecological transitions; a review. Agron Sustain Dev 35:1237-1257. doi:10.1007/s13593-015-0318-x 
EASAC (2015) Ecosystem services, agriculture and neonicotinoids. German National Academy of Science, Halle

Elzen B, Barbier M, Cerf M, Grin J (2012) Stimulating transitions towards sustainable farming systems. In: Darnhofer I, Gibbon D, Dedieu B (eds) Stimulating transitions towards sustainable farming systems. Farming systems research into the 21st century: the new dynamic. Springer, Dordrecht, pp. 431-455

Elzen B, Geels FW, Leeuwis C, van Mierlo B (2011) Normative contestation in transitions 'in the making': animal welfare concerns and system innovation in pig husbandry. Res Policy 40:263-275. doi:10.1016/j.respol.2010.09.018

ExpandNet (2011) Beginning with the end in mind. Planning pilot projects and other programmatic research for scaling up. World Health Organization (WHO)/Expandnet, Geneva

Faustino J, Booth D (2014) Development entrepreneurship: how donors and leaders can foster institutional change. Asia Foundation, San Francisco; Overseas Development Institute, London

Fischer ARH, Beers PJ, Latesteijn HV, et al. (2012) Transforum system innovation towards sustainable food. A review. Agron Sustain Dev 32:595-608. doi:10.1007/s13593-011-0067-4

Foran T, Butler JRA, Williams LJ, Wanjura WJ, Hall A, Carter L (2014) Taking complexity in food systems seriously: an interdisciplinary analysis. World Dev 61:85-101. doi:10.1016/j.worlddev.2014.03.023

Foresight (2011) The future of food and farming: challenges and choices for global sustainability. Final project report. The Government Office for Science, London

Freeman OE, Duguma LA, Minang PA (2015) Operationalizing the integrated landscape approach in practice. Ecol Soc 20:24. doi:10.5751/ES-07175-200124

Frodeman R, Klein JT, Mitchameds C (2010) The Oxford handbook of interdisciplinarity. Oxford University Press, New York

Fünfschilling L, Truffer B (2014) The structuration of socio-technical regimes - conceptual foundations from institutional theory. Res Policy 43:772-791. doi:10.1016/j.respol.2013.10.010

Garb Y, Friedlander L (2014) From transfer to translation: using systemic understandings of technology to understand drip irrigation uptake. Agric Syst 128:13-24. doi:10.1016/j.agsy.2014.04.003

Garcia JR, Zazueta A (2015) Going beyond mixed methods to mixed approaches: a systems perspective for asking the right questions. IDS Bull 46:30-43. doi:10.1111/1759-5436.12119

Gee D, Grandjean P, Hansen SF, et al. (eds) (2013) Late lessons from early warnings: science, precaution, innovation. EEA report No1/ 2013. European Environment Agency, Copenhagen

Geels FW (2001) Technological transitions as evolutionary reconfiguration processes: a multi-level perspective and a case-study. Paper presented at Nelson and Winter Conference, June 12-15, 2001, Aalborg, Denmark

Geels FW (2002) Technological transitions as evolutionary reconfiguration processes: a multi-level perspective and a case-study. Res Policy 31:1257-1274. doi:10.1016/S0048-7333(02)00062-8

Geels FW (2011) The multi-level perspective on sustainability transitions: responses to seven criticisms. Environ Innov Soc Transit 1: 24-40. doi:10.1016/j.eist.2011.02.002

Geels FW (2014) Regime resistance against low-carbon transitions: introducing politics and power into the multi-level perspective. Theor Cult Soc 0:1-20. doi:10.1177/0263276414531627

Geels FW, Schot J (2007) Typology of sociotechnical pathways. Res Policy 36:399-417. doi:10.1016/j.respol.2007.01.003

Genus A, Coles AM (2008) Rethinking the multi-level perspective of technological transitions. Res Policy 37:1436-1445. doi:10.1016/j. respol.2008.05.006

GEO (Grantmakers for Effective Organizations) (2011) How do networks support scale? Reframing the conversation: a GEO briefing paper series on growing social impact. Grantmakers for Effective Organizations, Washington, DC
German L, Mowo J, Kingamkono M (2006) A methodology for tracking the "fate" of technological interventions in agriculture. Agr Hum Values 23:353-369. doi:10.1007/s10460-006-9008-2

Ghiron L, Shillingi L, Kabiswa C, et al. (2014) Beginning with sustainable scale up in mind: initial results from a population, health and environment project in East Africa. Reprod Health Matters 22:84 92. doi:10.1016/S0968-8080(14)43761-3

Giller KE, Tittonell P, Rufino MC, et al. (2011) Communicating complexity: integrated assessment of trade-offs concerning soil fertility management within African farming systems to support innovation and development. Agric Syst 104:191-203. doi:10.1016/j. agsy.2010.07.002

Gouttenoire L, Cournut S, Ingrand S (2013) Participatory modelling with farmer groups to help them redesign their livestock farming system. Agron Sustain Dev 33:413-424. doi:10.1007/s13593-012-0112-y

Guillem EE, Murray-Rust D, Robinson DT, Barnes A, Rounsevell MDA (2015) Modelling farmer decision-making to anticipate tradeoffs between provisioning ecosystem services and biodiversity. Agric Syst 137:12-23. doi:10.1016/j.agsy.2015.03.006

Coenen L, Benneworth P, Truffer B (2012) Toward a spatial perspective on sustainability transitions. Res Policy 41:968-979. doi:10.1016/j. respol.2012.02.014

Hansen T, Coenen L (2015) The geography of sustainability transitions: review, synthesis and reflections on an emergent research field. Environ Innov Soc Transit 17:92-109. doi:10.1016/j. eist.2014.11.001

Hassink J, Grin J, Hulsink W (2013) Multifunctional agriculture meets health care: applying the multi-level transition sciences perspective to care farming in the Netherlands. Sociol Rural 53:223-245. doi:10.1111/j.1467-9523.2012.00579.x

Hermans F, Stuiver M, Beers PJ, Kok K (2013) The distribution of roles and functions for upscaling and outscaling innovations in agricultural innovation systems. Agric Syst 115:117-128. doi:10.1016/j. agsy.2012.09.006

Hinrichs CC (2014) Transition to sustainability: a change in thinking about food systems change? Agric Hum Values 31:143-155. doi:10.1007/s10460-014-9479-5

Hoang LA, Castella J-C, Novosad P (2006) Social networks and information access: implications for agricultural extension in a rice farming community in northern Vietnam. Agric Hum Values 23:513527. doi:10.1007/s10460-006-9013-5

Holtz G, Brugnach M, Pahl-Wostl C (2008) Specifying "regime"-a framework for defining and describing regimes in transition research. Technol Forecast Soc Chang 75:623-643. doi:10.1016/j. techfore.2007.02.010

Horlings LG, Marsden TK (2011) Towards the real green revolution? Exploring the conceptual dimensions of a new ecological modernisation of agriculture that could 'feed the world'. Glob Environ Chang 21:441-452. doi:10.1016/j.gloenvcha.2011.01.004

Hossain MF (2006) Arsenic contamination in Bangladesh — an overview. Agric Ecosyst Environ 113:1-16. doi:10.1016/j.agee.2005.08.034

IIRR (1999) Scale up! Highlights and synthesis of proceedings of the CGIAR NGO Committee Workshop on scaling up sustainable agriculture initiatives. The NGO Committee, Global Forum on Agricultural Research, CGIAR/World Bank

Ingram J (2015) Framing niche-regime linkage as adaptation: an analysis of learning and innovation networks for sustainable agriculture across Europe. J Rural Stud 40:59-75. doi:10.1016/j. jrurstud.2015.06.003

Jahanyan AA, Fard HD (2012) Utilising multi-aspectual understanding as a framework for ERP success evaluation. J Enterp Inf Manag 25: 479-504. doi:10.1108/17410391211265151

Jochemsen H (2012) Towards sustainable food production: a normative analysis of agrarian practice. In: Botes L, Willem E, Jongeneel R (eds) Re-integrating technology and economy in human life and society. Rozenberg Quarterly, Amsterdam, pp. 121-136 
Johnson RB, Onwuegbuzie AJ (2004) Mixed methods research: a research paradigm whose time has come. Educ Res 33:14-26. doi:10.3102/0013189X033007014

Joly P-B, Gaunand A, Colinet L, Larédo P, Lemarié S, Matt M (2015) ASIRPA: a comprehensive theory-based approach to assessing the societal impacts of a research organization. Res Eval 24:440-453. doi:10.1093/reseval/rvv015

Kemp R, Rotmans J (2009) Transitioning policy: co-production of a new strategic framework for energy innovation policy in the Netherlands. Policy Sci 42:303-322. doi:10.1007/s11077-009-9105-3

Kemp R, Schot J, Hoogma R (1998) Regime shifts to sustainability through processes of niche formation: the approach of strategic niche management. Technol Anal Strat Manag 10:175-195. doi:10.1080/09537329808524310

Kieboom M (2014) Lab matters: challenging the practice of social innovation laboratories. Kennisland, Amsterdam

Kilelu CW, Klerkx L, Leeuwis C (2013) Unravelling the role of innovation platforms in supporting co-evolution of innovation: contributions and tensions in a smallholder dairy development programme. Agric Syst 118:65-77. doi:10.1016/j.agsy.2013.03.003

Kivimaa P, Kern F (2016) Creative destruction or mere niche support? Innovation policy mixes for sustainability transitions. Res Policy 45: 205-217. doi:10.1016/j.respol.2015.09.008

Klein J (2014) Discourses of transdisciplinarity: looking back to the future. Futures 63:68-74. doi:10.1016/j.futures.2014.08.008

Klein Woolthuis R (2013) Institutional entrepreneurship in sustainable urban development: Dutch successes as inspiration for transformation. J Clean Prod 50:91-100. doi:10.1016/j.jclepro.2012.11.031

Klerkx L, Aarts N, Leeuwis C (2010) Adaptive management in agricultural innovation systems: the interactions between innovation networks and their environment. Agric Syst 103:390 400. doi:10.1016/j.agsy.2010.03.012

Klerkx L, Schut M, Leeuwis C, Kilelu C (2012) Advances in knowledge brokering in the agricultural sector: towards innovation system facilitation. IDS Bull 43:53-60. doi:10.1111/j.1759-5436.2012.00363.x

Knowler D, Bradshaw B (2007) Farmers' adoption of conservation agriculture: a review and synthesis of recent research. Food Policy 32: 25-48. doi:10.1016/j.foodpol.2006.01.003

Knutsson P (2006) The sustainable livelihoods approach: a framework for knowledge integration assessment. Hum Ecol Rev 13:90-99

Komarek AM, Bell LW, Whish JPM, Robertson MJ, Bellotti WD (2015) Whole-farm economic, risk and resource-use trade-offs associated with integrating forages into crop-livestock systems in western China. Agric Syst 133:63-72. doi:10.1016/j.agsy.2014.10.013

Koohafkan P, Altieri MA, Gimenez EH (2012) Green agriculture: foundations for biodiverse, resilient and productive agricultural systems. Int J Agric Sustain 10:61-75. doi:10.1080/14735903.2011.610206

Kozar R, Buck L, Barrow EG, et al. (2014) Toward viable landscape governance systems: what works? Landscapes for People, Food and Nature, Washington, DC

Kuehne G, Llewellyn R, Pannell D, Wilkinson R, Dolling P, Ouzman J (2013) ADOPT: the adoption and diffusion outcome prediction tool (public release version 1.0, June 2013) [computer software]. CSIRO, Adelaide SA Available from www.csiro.au/ADOPT

Lamichhane JR, Barzman M, Booij K, et al. (2015) Robust cropping systems to tackle pests under climate change. A review. Agron Sustain Dev 35:443-459. doi:10.1007/s13593-014-0275-9

Lamine C (2011) Transition pathways towards a robust ecologization of agriculture and the need for system redesign. Cases from organic farming and IPM. J Rural Stud 27:209-219. doi:10.1016/j. jrurstud.2011.02.001

Lamprinopoulou C, Renwick A, Klerkx L, Hermans F, Roep D (2014) Application of an integrated systemic framework for analysing agricultural innovation systems and informing innovation policies: comparing the Dutch and Scottish agrifood sectors. Agric Syst 129:40-54. doi:10.1016/j.agsy.2014.05.001
Leach M, Rockström J, Raskin P, et al. (2012) Transforming innovation for sustainability. Ecol Soc 17:11. doi:10.5751/ES-04933-170211

Leach M, Scoones I, Stirling A (2010) Dynamic sustainabilities: technology, environment, social justice. Routledge, Oxford

Leeuwis C (2000) Reconceptualizing participation for sustainable rural development: towards a negotiation approach. Dev Chang 31:931959. doi:10.1111/1467-7660.00184

Leeuwis C, Aarts N (2012) Rethinking communication in innovation processes: creating space for change in complex systems. J Agric Educ Ext 17:21-36. doi:10.1080/1389224X.2011.536344

Liebowitz SJ, Margolis SE (1995) Path dependence, lock-in, and history. J Law Econ Org 11:205-226. doi:10.2139/ssrn.1706450

Little M (2012) How to achieve lasting impact at scale. Summary. Social Research Unit, Dartington

Loveridge D (2009) Foresight. The art and science of anticipating the future. Routledge, New York

Maredia MK (2014) Impact assessment of agricultural research, institutional innovation, and technology adoption: introduction to the special section. Food Policy 44:214-217. doi:10.1016/j. foodpol.2013.10.001

Marquis C, Tilcsik A (2013) Imprinting: toward a multi-level theory. Acad Manag Ann 7:193-243. doi:10.1080/19416520.2013.766076

Massink H (2013) Blijvend thuis op aarde? Een historisch, systematisch en praktisch onderzoek naar de mogelijkheid van de operationalisering van het concept duurzaamheid, in het bijzonder voor de landbouw. Eburon, Delft

McNaghten P, Owen R, Stilgoe J, et al. (2014) Responsible innovation across borders: tensions, paradoxes and possibilities. J Respons Innov 1:191-199. doi:10.1080/23299460.2014.922249

Meadows DA (2009) Thinking in systems - a primer. Edited by Diana Wright. Earthscan, London

Melber H (ed) (2012) No future without justice. Report of the Civil Society Reflection Group on Global Development Perspectives. Development Dialogue, no. 59, June 2012. The Dag Hammarskjöld Foundation, Uppsala

Menter H, Kaaria S, Johnson N, Ashby J (2004) Scaling up. In: Pachico D, Fujisaka S (eds) Scaling up and out: achieving widespread impact through agricultural research. International Centre for Tropical Agriculture (CIAT), Cali, pp 9-23

Middleton T, de la Fuente T, Ellis-Jones J (2005) Scaling up successful pilot experiences in natural resource management. Lessons from Bolivia. In: Stocking M, Helleman H, White R (eds) Renewable natural resources management for mountain communities. ICIMOD, Kathmandu, pp. 221-238

Milder JC, Hart AK, Dobie P, Minai J, Zaleski C (2014) Integrated landscape initiatives for African agriculture, development, and conservation: a region-wide assessment. World Dev 54:68-80. doi:10.1016/j.worlddev.2013.07.006

Millar J, Connell J (2010) Strategies for scaling out impacts from agricultural systems change: the case of forages and livestock production in Laos. Agric Hum Values 27:213-225. doi:10.1007/s10460009-9194-9

Miller C, Newell B (2013) Framing integrated research to address a dynamically complex issue: the red headed cockchafer challenge. Agric Syst 117:13-18. doi:10.1016/j.agsy.2013.02.001

Mitchell C, Cordell D, Fam D (2015) Beginning at the end: the outcome spaces framework to guide purposive transdisciplinary research. Futures 65:86-96. doi:10.1016/j.futures.2014.10.007

Morrissey JE, Mirosa M, Abbott M (2014) Identifying transition capacity for agri-food regimes: application of the multi-level perspective for strategic mapping. J Environ Policy Plan 16: 281-301. doi:10.1080/1523908X.2013.845521

Nang'ole E, Mithöfer D, Franzel S (2011) Review of guidelines and manuals for value chain analysis for agricultural and forest products. ICRAF, Nairobi 
Nelson GC, Rosegrant MW, Palazzo A, et al. (2010) Food security, farming and climate change to 2050. IFPRI, Washington, DC

Olsson P, Galaz V, Boonstra WJ (2014) Sustainability transformations: a resilience perspective. Ecol Soc 19:1. doi:10.5751/ES-06799190401

Padt F, Opdam P, Polman N, Termeer C (eds) (2014) Scale-sensitive governance of the environment. Wiley, Chichester

Paillard S, Treyer S, Dorin B (eds) (2014) Scenarios and challenges for feeding the world in 2050. Springer, New York

Pannell DJ, Marshall GR, Barr N, Curtis A, Vanclay F, Wilkinson R (2006) Understanding and promoting adoption of conservation practices by rural landholders. Aust J Exp Agric 46:1407-1424. doi:10.1071/EA05037

Papachristos G, Sofianos A, Adamides E (2013) System interactions in socio-technical transitions: extending the multi-level perspective. Environ Innov Soc Transit 7:53-69. doi:10.1016/j.eist.2013.03.002

Pesch U (2014) Sustainable innovation, learning and responsibility. In: van den Hoven $J$ et al. (eds) Responsible innovation 1: innovative solutions for global issues. Springer, Dordrecht, pp. 199-218

Peshin R (2013) Farmers' adoptability of integrated pest management of cotton revealed by a new methodology. Agron Sustain Dev 33:563572. doi:10.1007/s13593-012-0127-4

Pohl C, Hirsch Hadorn G (2007) Principles for designing transdisciplinary research. Oekom Verlag, Munich

Reimer AP, Thompson AW, Prokopy LS (2012) The multi-dimensional nature of environmental attitudes among farmers in Indiana: implications for conservation adoption. Agric Hum Values 29:29-40. doi:10.1007/s10460-011-9308-Z

Ribeiro PF, Polinder H, Verkerk MJ (2012) Planning and designing smart grids: philosophical considerations. IEEE Technol Soc Mag 31:34 43. doi:10.1109/MTS.2012.2211771

Rogers EM (1983) Diffusion of innovations. Free Press, New York

Röling N (2009) Pathways for impact: scientists' different perspectives on agricultural innovation. Int J Agric Sustain 7:83-94. doi:10.3763/ijas.2009.0043

Röling N (2011) Africa can feed the world. Beyond expertise to new frontiers of trans-disciplinary science. UK Government's Foresight Project on Global Food and Farming Futures. Government Office for Science, London

Rotmans J (2003) Scaling in integrated assessment: problem or challenge? In: Rotmans J, Rothman DS (eds) Scaling in integrated assessment. Swets \& Zeitlinger, Lisse, pp. 300-327

Rotmans J, Rothman DS (eds) (2003) Scaling in integrated assessment. Swets \& Zeitlinger, Lisse

Roux DJ, Stirzaker RJ, Breen CM, Lefroy EC, Cresswell HP (2010) Framework for participative reflection on the accomplishment of transdisciplinary research programs. Environ Sci Pol 13:733-741. doi:10.1016/j.envsci.2010.08.002

Ruttan VW (1996) Induced innovation and path dependence: a reassessment with respect to agricultural development and the environment. Technol Forecast Soc Chang 53:41-59. doi:10.1016/0040-1625(96)00055-8

Sandker M, Campbell BM, Ruiz-Pérez M, et al. (2010) The role of participatory modelling in landscape approaches to reconcile conservation and development. Ecol Soc 15(2):13 [online] URL: http://www. ecologyandsociety.org/vol15/iss2/art13/

Sayer J, Sunderland T, Ghazoul J, et al. (2014) Ten principles for a landscape approach to reconciling agriculture, conservation, and other competing land uses. Proc Natl Acad Sci U S A 110:8349-8356. doi:10.1073/pnas. 1210595110

Scheffer M (2010) Complex systems: foreseeing tipping points. Nature 467:411-412. doi:10.1038/467411a

Scheffer M, Bascompte J, Brock WA, et al. (2009) Early-warning signals for critical transitions. Nature 461:53-59. doi:10.1038/nature08227

Schewe RL, Stuart D (2015) Diversity in agricultural technology adoption: how are automatic systems used and to what end.
Agric Hum Values 32:199-213. doi:10.1007/s10460-0149542-2

Schulze R (2000) Transcending scales of space and time in impact studies of climate and climate change on agrohydrological responses. Agric Ecosyst Environ 82:185-212. doi:10.1016/S0167-8809(00)00226-7

Schut M, Leeuwis C, van Paassen A, Lerner A (2011) Knowledge and innovation management in the policy debate on biofuel sustainability in Mozambique: what roles for researchers? KM4D J 7:45-64. doi:10.1080/19474199.2011.593874

Schut M, Rodenburg J, Klerkx L, van Ast A, Bastiaans L (2014a) Systems approaches to innovation in crop protection. A systematic literature review. Crop Prot 56:98-108. doi:10.1016/j.cropro.2013.11.017

Schut M, van Paassen A, Leeuwis C, Klerkx L (2014b) Towards dynamic research configurations: a framework for reflection on the contribution of research to policy and innovation processes. Sci Public Policy 41:207-218. doi:10.1093/scipol/sct048

Schut M, Klerkx L, Rodenburg J, et al. (2015a) RAAIS: rapid appraisal of agricultural innovation systems (part I). A diagnostic tool for integrated analysis of complex problems and innovation capacity. Agric Syst 132:1-11. doi:10.1016/j.agsy.2014.08.009

Schut M, Klerkx L, Sartas M, et al. (2015b) Innovation platforms: experiences with their institutional embedding in agricultural research for development. Exp Agric First View. doi:10.1017 /S001447971500023X

Schwab P, Cerutti F, Von Reibnitz UH (2003) Foresight - using scenarios to shape the future of agricultural research. Foresight 5:55-61. doi:10.1108/14636680310471299

Scoones I (1998) Sustainable rural livelihoods: a framework for analysis. IDS Working Paper 72. Institute of Development Studies (IDS), Brighton

Shiferaw BA, Okello J, Reddy RV (2009) Adoption and adaptation of natural resource management innovations in smallholder agriculture: reflections on key lessons and best practices. Environ Dev Sustain 11:601-619. doi:10.1007/s10668-007-9132-1

Shove E, Walker G (2007) CAUTION! Transitions ahead: politics, practice, and sustainable transition management. Environ Plan A 39: 763-770. doi:10.1068/a39310

Shove E, Walker G (2010) Governing transitions in the sustainability of everyday life. Res Policy 39:471-476. doi:10.1016/j. respol.2010.01.019

Sinclair K, Curtis A, Mendham E, Mitchell M (2014) Can resilience thinking provide useful insights for those examining efforts to transform contemporary agriculture? Agric Hum Values 31:371-384. doi:10.1007/s10460-014-9488-4

Spielman D, Davis K, Negash M, Ayele G (2011) Rural innovation systems and networks: findings from a study of Ethiopian smallholders. Agric Hum Values 28:195-212. doi:10.1007/s10460-010-9273-y

Spielman DJ, Ekboir J, Davis K (2009) The art and science of innovation systems inquiry: applications to Sub-Saharan African agriculture. Technol Soc 31:399-405. doi:10.1016/j.techsoc.2009.10.004

Spruijt P, Knol AB, Vasileiadou E, Devilee J, Lebret E, Petersen AC (2014) Roles of scientists as policy advisers on complex issues: a literature review. Environ Sci Pol 40:16-25. doi:10.1016/j. envsci.2014.03.002

Stern PC (2000) Toward a coherent theory of environmentally significant behaviour. J Soc Issues 56:407-424. doi:10.1111/0022-4537.00175

Stilgoe J, Owen R, McNaghten P (2013) Developing a framework for responsible innovation. Res Policy 42:1568-1580. doi:10.1016/j. respol.2013.05.008

Stirling A (2009) Direction, distribution, diversity! Pluralising progress in innovation, sustainability and development. STEPS Working Paper 32, STEPS Centre, University of Sussex, Brighton, UK

Stirling A (2011) Pluralising progress: from integrative transitions to transformative diversity. Environ Innov Soc Transit 1:82-88. doi:10.1016/j.eist.2011.03.005 
Stirling A (2015) Towards innovation democracy? Participation, responsibility and precaution in the politics of science and technology, STEPS Working Paper 78. STEPS Centre, Brighton, UK

Stokols D, Lejano RP, Hipp J (2013) Enhancing the resilience of humanenvironment systems: a social ecological perspective. Ecol Soc 18: 7. doi:10.5751/ES-05301-180107

Strijbos S, Basden A (eds) (2006) In search of an integrative vision of technology: interdisciplinary studies in information systems. Springer, New York

Sumberg J, Thompson J, Woodhouse P (2013) Why agronomy in the developing world has become contentious. Agric Hum Values 30: 71-83. doi:10.1007/s10460-012-9376-8

Sutherland LA, Peter S, Zagata L (2015) Conceptualising multi-regime interactions: the role of the agriculture sector in renewable energy transitions. Res Policy 44:1534-1554. doi:10.1016/j.respol.2015.05.013

Tenywa MM, Rao KPC, Tukahirwa JB, et al. (2011) Agricultural innovation platform as a tool for development oriented research: lessons and challenges in the formation and operationalization. J Agr Environ Stud 2:117-146

Thornton PH, Ocasio W (1999) Institutional logics and the historical contingency of power in organizations: executive succession in the higher education publishing industry, 1958-1990. Am J Sociol 105: 801-843. doi:10.1086/210361

Thuo M, Bell AA, Bravo-Ureta BE, et al. (2014) Effects of social network factors on information acquisition and adoption of improved groundnut varieties: the case of Uganda and Kenya. Agric Hum Values 31:339-353. doi:10.1007/s10460-014-9486-6

Turnhout E, Stuiver M, Klostermann J, Harms B, Leeuwis C (2013) New roles of science in society: different repertoires of knowledge brokering. Sci Public Policy 40:354-365. doi:10.1093/scipol/scs114

Turner JA, Klerkx L, Rijswijk K, Williams T, Barnard T (2016) Systemic problems affecting co-innovation in the New Zealand Agricultural Innovation System: identification of blocking mechanisms and underlying institutional logics. NJAS - Wagen J Life Sci 76:99-11. doi:10.1016/j.njas.2015.12.001

UNICEF (2012) Innovation labs. Do-it-yourself guide. UNICEF, New York

van den Berg H, Zaim M, Yadav RP, et al. (2012) Global trends in the use of insecticides to control vector-borne diseases. Environ Health Perspect 120:577-582. doi:10.1289/ehp.1104340

van den Hoven J, Doorn N, Swierstra T, Koops B-J, Romijn H (eds) (2014) Responsible innovation 1. Innovative solutions for global issues. Springer, Dordrecht

van der Ploeg JD (1993) Over de betekenis van verscheidenheid (On the meaning of diversity). Inaugural address, Wageningen University, Wageningen

van der Ploeg JD (2006) Agricultural production in crisis. In: Cloke P et al. (eds) The handbook of rural studies. Sage, London, pp. 258278

van der Stoep J, Strijbos S (2011) From technology transfer to intercultural development. Rozenberg Publishers, Amsterdam

van Ittersum MK, Ewert F, Heckelei T, et al. (2008) Integrated assessment of agricultural systems - a component-based framework for the European Union (SEAMLESS). Agric Syst 96:150-165. doi:10.1016/j.agsy.2007.07.009

van Kerkhoff L (2014) Developing integrative research for sustainability science through a complexity principle-based approach. Sustain Sci 9:143-155. doi:10.1007/s11625-013-0203-y
Veldkamp A, van Altvorst AC, Eweg R, et al. (2009) Triggering transitions towards sustainable development of the Dutch agricultural sector: TransForum's approach. Agron Sustain Dev 29:87-96. doi:10.1051/agro:2008022

Vervoort JM, Thornton PK, Kristjanson P, et al. (2014) Challenges to scenario-guided adaptive action on food security under climate change. Glob Environ Chang 28:383-394. doi:10.1016/j. gloenvcha.2014.03.001

Volk M, Ewert F (2011) Scaling methods in integrated assessment of agricultural systems - state-of-the-art and future directions. Agric Ecosyst Environ 142:1-5. doi:10.1016/j.agee.2010.10.014

Wagner CS, Roessner JD, Bobb K, et al. (2011) Approaches to understanding and measuring interdisciplinary scientific research (IDR): a review of the literature. J Infometr 5:14-26. doi:10.1016/j. joi.2010.06.004

Weichselgartner J, Kasperson R (2010) Barriers in the science-policypractice interface: toward a knowledge-action-system in global environmental change research. Glob Environ Chang 20:266-277. doi:10.1016/j.gloenvcha.2009.11.006

Wejnert B (2002) Integrating models of diffusion of innovations. A conceptual framework. Annu Rev Sociol 28:297-306. doi:10.1146/annurev.soc.28.110601.141051

Westley FR, Antadze N, Riddell DJ, Robinson K, Geobey S (2014) Five configurations for scaling up social innovation: case examples of non-profit organizations from Canada. J Appl Behav Sci 50:234260. doi: $10.1177 / 0021886314532945$

Westley FR, Tjornbo O, Schultz L, et al. (2013) A theory of transformative agency in linked social-ecological systems. Ecol Soc 18:27. doi:10.5751/ES-05072-180327

Wigboldus S, Leeuwis C (2013) Toward responsible scaling up and out in agricultural development. An exploration of concepts and principles. Centre for Development Innovation \& Knowledge, Technology and Innovation group. Wageningen University and Research centre, Wageningen

Willemen L, Hart A, Negra C et al (2013) Taking tree-based ecosystem approaches to scale. Evidence of drivers and impacts on food security, climate change, resilience, and carbon sequestration. EcoAgriculture Discussion Paper No. 11. EcoAgriculture Partners, Washington, DC

Wittmayer JM, Schäpke N (2014) Action, research and participation: roles of researchers in sustainability transitions. Sustain Sci 9:483496. doi:10.1007/s11625-014-0258-4

Woodham-Smith C (1962) The great hunger: Ireland 1845-1849. Harper and Row, New York

Wu J (2013) Landscape sustainability science: ecosystem services and human well-being in changing landscapes. Landsc Ecol 28:999 1023. doi:10.1007/s10980-013-9894-9

Wu J, Jones KB, Li H, Loucks OL (eds) (2006) Scaling and uncertainty analysis in ecology. Methods and applications. Springer, New York

Xu J, Grumbine RE, Beckschäfer P (2014) Landscape transformation through the use of ecological and socioeconomic indicators in Xishuangbanna, Southwest China, Mekong Region. Ecol Indic 36: 749-756. doi:10.1016/j.ecolind.2012.08.023

Yu Q, Wu W, Yang P, Li Z, Xiong W, Tang H (2012) Proposing an interdisciplinary and cross-scale framework for global change and food security researches. Agric Ecosyst Environ 156:57-71. doi:10.1016/j.agee.2012.04.026

Ziegler AD, Fox JM, Xu J (2009) The rubber juggernaut. Science 324: 1024-1025. doi:10.1126/science.1173833 